\title{
A triász és a jura idôszak határán lezajlott globális krízis és annak nyomai magyarországi rétegsorokban
}

\author{
HAAs János ${ }^{1}$, GYőRi Orsolya ${ }^{1}$, Kocsis T. Ádám², ${ }^{2}$, LANTOS Zoltán ${ }^{4}$, PÁLFY József ${ }^{3,5}$ \\ 'MTA-ELTE Geológiai, Geofizikai és Űrtudományi Kutatócsoport, 1117 Budapest, Pázmány Péter sétány 1/c \\ (haas@caesar.elte.hu; gyori.orsi@gmail.com) \\ ${ }^{2}$ GeoZentrum Nordbayern, Department of Geography and Geosciences, Universität Erlangen-Nürnberg, Loewenichstraße 28, 91054 Erlangen, \\ Németország (adam.kocsis@fau.de) \\ ${ }^{3}$ MTA-MTM-ELTE Paleontológiai Kutatócsoport, 1117 Budapest, Pázmány Péter sétány 1/c \\ ${ }^{4}$ Magyar Bányászati és Földtani Szolgálat, 1145 Budapest, Columbus utca 17-23 (lantos.zoltan@ mbfsz.gov.hu)
}

\section{Global crisis at the Triassic-Jurassic boundary and its stratigraphic record in Hungary}

Abstract

The mass extinction at the end of the Triassic Period was one of the largest extinction events in the Phanerozoic and it was the result of a global environmental crisis. In connection with this, the last two decades have seen increasing research efforts to gain more knowledge and thus a better understanding of this event. These efforts have included detailed studies of numerous stratigraphic sections worldwide. The review presented here attempts to summarize the major results of multi-faceted international research on the stratigraphic and fossil record of the end-Triassic event, discussing proposed cause-and-effect relationships and possible scenarios. In addition, there is also an overview of studies made in recent decades on the Triassic-Jurassic boundary sections in Hungary, with an emphasis on their relevance to global research into the Triassic-Jurassic boundary.

Keywords: global environmental crisis, mass extinction, Triassic-Jurassic boundary

Összefoglalás

A triász időszakot lezáró tömeges kihalás egyike a fanerozoikum legnagyobb kihalási eseményeinek, amelyet globális környezeti krízis idézhetett elő. Kutatása az elmúlt két évtizedben vált intenzívvé és azóta szerte a világon, számos szelvény részletes vizsgálatával folyik. A szemle jellegú cikk célja a környezeti krízis kőzetekben megő́rződött nyomainak felderítését célzó rendkívül kiterjedt és szerteágazó kutatások fontosabb eredményeinek és a folyamatokat kiváltó okok értelmezésének áttekintése, valamint a hazai triász-jura határképződmények jelentőségének és a szelvények vizsgálatával eddig szerzett ismereteknek az összegző bemutatása.

Tárgyszavak: globális környezeti krízis, tömeges kihalás, triász-jura határ

\section{Bevezetés}

A földtani kutatások eredményeként régóta tudjuk, hogy voltak a Föld történetében olyan, viszonylag rövid idejű környezeti krízisek, amelyek az élővilág igen jelentős megváltozását eredményezték, amikor tömegesen haltak ki fajok, nemzetségek, sőt a szervezetek nagyobb csoportjai is. Ezek a krízisek nemegyszer döntôen megváltoztatták az élővilág fejlődésének további menetét. Bolygónk történetét szakaszokra tagolják és ily módon a földtörténetben mérföldköveknek tekinthetők. Azt, hogy az ősmaradványegyüttesekben hirtelen, jelentős változások vannak már a 19. század első felében felismerték. Ezeknél a változásoknál vonták meg a földtörténeti időszakok határát és az 1820_ 1840 között elnevezett időszakok (pl.: szilur, devon, triász, jura, kréta) máig érvényben vannak. 1841-ben John PHILLIPS javasolta az állatvilág fejlettségén alapuló tagolást, megalkotva a paleozoikum, mezozoikum és kainozoikum terminusokat (MORRELL 2001).

A földtörténet legutolsó, mintegy fél milliárd évének legnagyobb tömeges kihalási eseményeit RAUP \& SEPKOSKI (1982) az ôsmaradvány anyag korszerú elemzésével mutatta ki. A kihalási ráta változásait ábrázoló diagramjukon öt feltûnő kihalási csúcs jelentkezik: az ordovícium végén, a késő-devonban, a perm végén, a triász végén és a kréta végén. Az öt legnagyobb közt van a tehát a paleozoikum-mezozoikum és a mezozoikum-kainozoikum határa is. Ez jól mutatja, hogy az élővilág összetételének változásai ezeknél a fordulópontoknál olyan erôteljesek voltak, hogy azokat a rétegtan kialakulásának hajnalán is felismerhették a rétegsorok tagolásán fáradozó kutatók.

Alvarez et al. (1980) hatalmas figyelmet kiváltó tanul- 
mánya a mezozoikum végi kihalást aszteroida-becsapódásra vezette vissza. Mivel a későbbiekben is számos bizonyíték támasztotta alá ALvarez hipotézisét (Schulte et al. 2010), a kutatók jelentôs csoportja azt feltételezte, hogy valamennyi nagy krízis égitest-becsapódás hatására bekövetkezett, az élővilág számára kedvezőtlen környezeti változások sorozatára vezethetô vissza (RAMPINo et al. 1997, RAUP 1992). A fanerozoikumban a legnagyobbnak tekinthetô, a paleozoikumot lezáró krízis beható tanulmányozása azonban nem támasztotta alá ezt a feltételezést. A Manicouagan krátert létrehozó becsapódást hozták összefüggésbe a határeseménnyel (OLSEN et al. 1987). A becsapódás során képződött olvadékkőzetek U-Pb kormeghatározása azonban a határesemény idejénél 10 millió évvel idősebb kort adott (HoDYCH \& DunNING 1992) és a becsapódás jelzójének tekintett irídiumkoncentráció is több nagyságrenddel kisebb volt a kréta-paleocén határnál észleltnél. Ugyanakkor egyre inkább alátámasztást nyert az az elképzelés, hogy a perm végi tömeges kihalást, az azzal egy idôben hatalmas tömegú anyagot felszínre hozó szibériai platóbazalt-vulkanizmushoz lehetne kötni (RENNE \& BASU 1991, SoBoLEv et al. 2011). Ezzel párhuzamosan merült fel az az elképzelés, hogy a triász-jura határon észlelt tömeges kihalást ugyancsak egy rendkívül kiterjedt magmafeltörési eseménnyel, a Közép-Atlanti magmás provincia (KAMP) vulkanizmusával lehetne kapcsolatba hozni (MARzoli et al. 1999, PÁlfy et al. 2000, Hesselbo et al. 2002). Az ezredforduló tájékán ezzel került a triász végi kihalási esemény is a kutatók érdeklődésének előterébe.

Szemle jellegú tanulmányunk célja kettôs. Egyrészt a rendelkezésre álló bôséges irodalom alapján áttekintést kívánunk adni a triász időszakot lezáró globális környezeti krízissel és az ahhoz köthető tömeges kihalással kapcsolatos kutatások fontosabb eredményeiről és a határesemény értelmezésével kapcsolatos jelenlegi elképzelésekról. Másrészt be kívánjuk mutatni a hazai triász-jura határszelvények vizsgálatának eddigi eredményeit, hiszen olyan szelvényekkel is rendelkezünk, amelyek fontos információkkal szolgálhatnak a földtörténetben jelentős fordulatot hozó globális események megértéséhez, illetve azok regionális és lokális hatásainak értelmezéséhez.

\section{A triász és a jura idôszak határának kérdése}

A határesemények áttekintése elôtt nem kerülhetô meg az a kérdés, hogy hogyan áll a határ megvonásának kérdése, mi a határmegvonás alapja, melyek a rétegtani határ korrelálásának problémái és az sem, hogy hogyan viszonyul a rétegtani határ a környezeti krízishez és az ahhoz köthető tömeges kihalási eseményhez. A mai kronosztratigráfiai rendszerben az egységek határának megvonása a globális sztratotípus szelvény és pont (GSSP) elvén alapul (REMANE 2003). Ennek lényege, hogy szóba jöhetô szelvényekre vonatkozó kutatási adatok áttekintését követôen az illetékes szakembereknek egy formalizált egyeztetési és szavazási eljárásrend keretében döntést kell hozniuk, hogy egy adott egység alsó határát mely szelvény, mely pontjánál definiálják. Ide kerül az „aranyszög”, és ezután ez az etalon, a Földön valamennyi szelvény esetében a határt ehhez a ponthoz kell viszonyítani. A határsztratotípus kiválasztásának fontos alapelve a rétegsor folyamatossága, zavartalansága (tektonikai, szedimentológiai szempontból), a legkülönbözőbb rétegtani módszerekkel (biosztratigráfia, kemosztratigráfia, magnetosztratigráfia, szekvenciasztratigráfia, radiomertikus kormeghatározás stb.) történô korrelálhatósága, és a kutatók számára való hozzáférhetősége is. A szelvényen belül a pontot többnyire a kronosztratigráfiai egység legalsó szakaszát definiáló biozóna alsó határánál rögzítik. Ha a szelvény és a pont kiválasztása jól sikerül, akkor azzal a rétegtani határ egyértelmúen megadható és ez reményt adhat a legkülönbözőbb környezetekben létrejött rétegsorok krono-korrelációjára. Hangsúlyozni kell azonban, hogy a biosztratigráfiai alapú pontkijelölés miatt, éppen a nagy krízisek esetében a rétegtani határ nem feltétlenül pontosan egyidejú a határesemény(ek) idópontjával.

Évtizedes szakmai vitát és szavazások sorát követôen, a jura alsó határának hivatalos, a Nemzetközi Rétegtani Bizottság által jóváhagyott definiálása 2009-ben megtörtént. A sztratotípust Ausztriában, az Északi-Mészkőalpok területén Kuhjochnál jelölték ki, az „aranyszöget” a Psiloceras spelae tirolicum első előfordulásának szintjéhez rögzítették (HillebrandT et al. 2013). Sajnos a kijelölt szelvény aligha tekinthető optimálisnak. Bár a szükséges biosztratigráfiai és geokémiai vizsgálatokat elvégezték, de a szerkezetföldtani kutatás elmaradt. A közelmúltban elvégzett részletes szerkezetföldtani vizsgálatok arra az eredményre vezettek, hogy a kijelölt szelvény erősen tektonizált, és egyes, a határ szempontjából kritikus fontosságú részei, tektonikai okok miatt, hiányoznak (PALOTAI et al. 2017). Így tehát a szelvény nem tekinthetô folyamatosnak és nem teljesen felel meg a sztratotípus szelvényekre vonatkozó szigorú kívánalmaknak. A sztratotípussal kapcsolatos problémák azonban nem akadályozzák számottevően a határesemény vizsgálatát, hiszen a rendelkezésre álló rétegtani eszközökkel a szelvények egymással való korrelációja kielégíthetően megoldható.

\section{Változások az élóvilágban}

Jelenlegi ismereteink szerint a triász idôszakot lezáró tömeges kihalás a fanerozoikum egyik legnagyobb kihalási rátájával jellemezhető eseménye volt (ALROY 2008, 2014). Az ökológiai szempontból kedvezôtlen hatások, mint a globális felmelegedés és az óceán savasodása (1. alább) elsősorban a tengeri ökoszisztémát sújthatták, továbbá az ősmaradványok megőrződésének feltételei is jellemzően a tengerekben kedvezőbbek. Az ôsmaradvány-együttesek összetételében jelentkezô változásokat globális (pl. a Paleobiology Database, Kocsis et al. 2015) illetve taxonspecifikus adatsorok elemzésével tudjuk felmérni.

Kevéssé ismert az eseménynek a tápláléklánc alapját adó, az elsődleges produkciót végző szervezetekre gyakorolt hatása. Habár a triász vége előtt a mészvázú nanno- 
plankton szervezetek diverzitása és gyakorisága viszonylag alacsony volt (Bown et al. 2004), az eddigi kutatások lecsökkenő produkcióról (CLÉMENCE et al. 2010) és lokálisan megfigyelhető kihalásokról (vAN DE SCHOOTBRUGGE et al. 2007) számoltak be. A planktonikus szervezetek közül egyedül a radiolariák rendelkeznek a globális elemzésekhez megfelelő mértékú diverzitással és megôrzôdési potenciállal. Ebben a csoportban jelentős mértékú kihalás igazolható. A csoportra jellemző kova vázanyag miatt a kihalást aligha okozhatta óceánsavasodás, sokkal valószínúbb az, hogy a tengervíz megemelkedett hőmérsékletének lehetett meghatározó szerepe (Kocsis et al. 2014).

A nektonikus szervezetek közül a triász-jura határhoz kötődő kihalás során teljesen eltúnt a Conodonta csoport, és jelentős taxonómiai átrendeződés zajlott le az ammoniteszeken belül is (GUEX et al. 2012). Habár a jelenlegi adatbázisalapú tanulmányok fokozatos diverzitáscsökkenésrôl számolnak be mindkét csoport esetében (BRAYARD et al. 2009, ORCHARD 2010), az esemény értelmezése az előfordulás-alapú Paleobiology Database segítségével mindeddig nem történt meg, így feltehető, hogy a háttérhez képest megemelkedett kihalások (különösen az ammoniteszek esetében) a SignorLipps hatás miatt (SIGNOR \& LIPPS 1982) nem mutathatóak ki.

Mivel a mezozoikumi bentosz közösségek magasabb rendû taxonjai a modern ökoszisztémákban is jelentős számban vannak jelen, azok fiziológiájáról, élőhely-preferenciáiról, illetve ökológiai körülményeiről sokkal többet tudunk, mint a nektonikus élőlények paramétereiről. Ezeket a változókat felhasználva az előfordulási adatbázisok elemzésekor betekintést nyerhetünk a kihalási események mechanizmusába és feltárhatóvá válnak azok ok-okozati összefüggései. Bár egy klasszikus északi-mészkőalpi szelvényben óceánsavasodással összefüggésbe hozható változásokat figyeltek meg a kagylóegyütteseken (MCRoBERTS et al. 2012), a kihalási eseményt nem sikerült a váz anyagának megváltozásával magyarázni. Ezzel szemben a partközeli élőhelyú és a zátonyszervezetek körében észlelt kihalások emelkedése statisztikailag igazolható (KIESSLING et al. 2007). A triász-jura tömeges kihalási esemény feltehetően a földtörténet egyik legnagyobb zátonykrízisével esett egybe (KIESSLING \& SimPSON, 2011). Emelett tömegesen tûntek el különösen vastag mészvázat elválasztó (hiperkalcifikáló) fajok a Scleractinia, Bivalvia, Gastropoda csoportokban, míg egyes nem mészvázú formák számottevő veszteségek nélkül átvészelték a megváltozott környezeti állapotokat (pl. Lingulidae brachiopoda csoport). A korallokat érintő szignifikáns kihalást LATHUILIÈRE \& MARCHAL (2009) független elemzése is alátámasztotta, ami a trópusi affinitással rendelkező csoportok szelektív eltúnése mellett (KIESSLING \& ABERHAN, 2007) ugyancsak megerősíti a hőmérséklet változásának szerepét a kihalások magyarázatában.

A szárazföldi élővilágban is nyomon követhető a két időszak határán bekövetkezett környezetváltozás. A növényvilág reakciója mind palinológiai, mind paleobotanikai adatok segítségével kimutatható. Jelentős palinológiai változásokról számoltak be Marokkóból és Észak-Amerikából a Közép-Atlanti magmás provinciához (KAMP) köthető riftmedencék rétegsoraiban (CIRILLI 2010). Különös ismertetőjegye a határeseménynek a „triász-jura spóra csúcs” (FowELL et al. 1994), amelynek jelenlétét később további szelvényekből is megerősítették. A spóra csúcs és a tengeri Prasinophyta algák gyakorisági csúcsának egybeesését érvként használták fel annak bizonyítására, hogy a szárazföldi és a tengeri ökoszisztémák zavara hasonló időpontban történhetett (GöTz et al. 2009). Ez a jelenség azonban pl. a St. Audrie's Bay szelvényben, ciklikusan visszatérően jelentkezik (Bonis et al. 2010a). CiRILli (2010) összefoglaló munkájában amellett érvel, hogy a késő-triász során fokozatos változások játszódtak le, és klímavezérelt ciklikus vegetációváltozások jellemezték a triász-jura határintervallumot.

A paleobotanikai adatok nem jeleznek szignifikáns kihalást a határintervallumban, de számos területen (pl. KeletGrönlandon, HARRIS 1937) találtak lokális flórakicserélődésre utaló nyomokat. McELWAIN et al. (1999) levélmaradványok ezreinek vizsgálata alapján érveltek az ökoszisztéma összeomlása mellett. A relatív gyakoriság-eloszlások megváltozása alapján valószínûsíthető a diverzitás csökkenése a triász-jura határon, amely egybeesik a sztómasưrűség alapján számolt légköri $\mathrm{CO}_{2}$-koncentráció hirtelen növekedésével (McElWAin et al. 2007, 2009; STEINTHORTSDOTTIR et al. 2011), ami megerôsíti a globális felmelegedés szerepét a kihalási eseménysorozatban. Ezzel szemben az európai kontinentális területekról származó palinológiai és paleobotanikai adatok nem utalnak az ökoszisztéma jelentős érintettségére (BARBACKA et al. 2017). Ennek alapján tehát megkérdőjelezhető a megfigyelt változások globális jellege.

A szárazföldi gerincesek jelentős faunaváltására utaló jelek is megfigyelhetőek a jó rétegtani felbontású északamerikai rétegsorokban (OLSEN et al. 2002). Globális elemzések alapján feltételezhető, hogy a triász-jura határ fordulópont volt az őshüllők fejlődéstörténetében. A korábban nagyobb taxonómiai és morfológiai diverzitással rendelkező Crurotarsi csoport szerepét a dinoszauruszok vették át (BRUSATTE et al. 2008), a mezozoikum hátralevő részében uralva a szárazföldi ökoszisztémákat.

\section{Változások az üledékképzódésben}

Számos tengeri rétegsor esetében észlelhető litológiai változás a triász-jura határ közelében, de vannak olyan folyamatos rétegsorok is, ahol fokozatos, trendszerú változás észlelhetô, vagy egyáltalán nincs lényegesebb változás. Részletes elemzést igényel az egyes rétegsorokban megfigyelhető litológiai változások jellegének kiderítése, tehát annak megállapítása, hogy a változások trendszerúek, ciklusosak, vagy egy-egy rövid idejű eseményhez köthetők. Az elemzések azt mutatják, hogy általában mindezek együtt vannak jelen. Nem egyszerú a szelvényekben megfigyelt jelenségek értelmezése, hiszen azok számos tényező együttes hatását tükrözik. Ezek közül a tengerszint és a klíma változásai tekinthetők meghatározónak. Mindezekre szuperponálódik az a hatás, amit a tömeges kihalásokhoz veze- 
tő környezeti krízis idézett elő. Ami a klímát illeti, azt globálisan a melegházi (greenhouse) klímaállapot és a megamonszun-rendszer hatása határozza meg. A nyugati Tethys és Peri-Tethys régióban a nori legvégén a klíma humiddá vált, ami a legtöbb medencében a nagy mennyiségú terrigén anyag beszállítódásához vezetett. A tengerszintváltozás leglényegesebb eleme, hogy a késő-rhaeti alacsony tengerszintû szakasz után a jura korai szakaszát tengerszint-emelkedés jellemzi.

A medence rétegsorokat illetően a litológiai változások elsôsorban a finom terrigén sziliciklasztos komponens (agyag, kőzetliszt) és a szervesanyag-tartalom változásaiban nyilvánulnak meg. A határintervallumban sok szelvényben megjelenő szerves anyagban gazdag agyagos-karbonátos kőzetfajtákra a vékony lemezes kőzetszerkezet jellemző. Mindez anoxikus lerakódási környezetet jelez. NyugatEurópa, Észak- és Dél-Amerika területének kiterjedt selfmedencéiben ismertek ilyen rétegsorok.

Az Anglia délnyugati és Wales déli részén húzódó, részletesen és sokoldalúan vizsgált, viszonylag sekély medencében, illetve annak rámpa jellegú peremén lerakódott rétegsorok határszelvényei fontos adatokat szolgáltattak a határ intervallumban lezajlott üledékföldtani változásokat és azok értelmezését illetően. HessELbo et al. (2004) a határszelvények litológiai változásait elsősorban a tengerszintváltozásokra vezette vissza. A rhaeti késői szakaszában, relatív vízszintemelkedés következményeként nagy elterjedésú feketepala képződött, amire a tengerszint-emelkedés megállását követően felfelé durvuló, partközeli üledéksor következik. A határ az ezt követô vízszintemelkedés során lerakódott sziliciklasztos-karbonátos rétegcsoporton belül vonható meg, amire a hettangi legalsó részét képviselő karbonátrámpa üledékei következnek.

A vastag karbonátplatform-rétegsorok folyamatos és jelentős aljzatsüllyedést jeleznek. Az egészséges platformok üledékképződése az elsô-, másod- és harmadrendû tengerszint változásokkal lépést tud tartani (SCHLAGER 1981, GOLDHAMMER et al. 1993). A megfulladt karbonátplatformok fölött lerakódott hemipelágikus, majd pelágikus rétegsorokban az átöröklött (pl. Adnet), vagy lokális szerkezetalakulás hatására kialakult aljzati tagolódás hosszú időn keresztuil, akár a jura végéig megőrződött és alapvetôen befolyásolta az üledékképződés jellegét (Vörös \& GALÁCZ 1998). A áramlatok által söpört tenger alatti magaslatokon vékonyabb, kondenzált és hézagos rétegsorok, míg a hátságok közötti medencékben vastagabb és folyamatosabb pelágikus összletek rakódtak le (GALÁCZ \& VöRÖS 1972, BERNOULLI \& JENKYNS 1974). A hátságok peremét áthalmozott biodetrituszos mészkövek, szinszediment breccsák és üledékes telérek megjelenése jellemzi (GALÁCz 1988, VöRÖs 1991).

Az alpi térségben a késô-triász-kora-jura szedimentáció jellegét egyrészt a Neotethys perem extenziója és a későbbi Alpi Tethys riftesedése során létrejövő extenziós medencék kialakulása, másrészt a klimatikus viszonyok és a tengerszintváltozások határozták meg. Az extenzióval és blokk-tektonikával jellemezhető kora- és középső-liászban (pl. Bernoulli \& JenKyns 1974) azonban a megfulladás időpontjai az egyes platformszegmensekben nem estek egybe az extenziós tektonikai aktivitás intenzitásának lokális csúcspontjaival (BERTOTTI et al. 1993). A riftesedésnek, illetve az ehhez kapcsolható szerkezetalakulásnak tehát meghatározó szerepe lehetett abban, hogy a megfulladás a platform mely részeit érintette, annak idejét azonban más tényezôk (pl. tengerszintváltozás, a víz átvilágítottságának változása, karbonáttermelő szervezetek) is lényegesen befolyásolhatták (PICOTTI \& COBIANCHI 1996).

Az Alpi Tethys riftesedésének megindulásához köthetően a nori középső részén az Északi-Mészkőalpok nagy kiterjedésú Dachsteini platformjának belsô része medencévé vált (Seefeld F., "Plattenkalk"), amelyben azt követően agyagos-karbonátos rétegsorok rakódtak le (Kösseni Formáció). A késô-rhaetiben azonban a Kösseni-medence jelentős részein ismét karbonátplatformok alakultak ki, míg egyes gyorsabban süllyedő medencerészeken a Kösseni Formáció képződése a rhaeti legkésőbbi szakaszáig folytatódott (GAwLICK et al. 1999). A platformok megfulladása a rhaeti végén következett be (GAWLICK et al. 1999). A medence területeken a Kösseni Formációra éles határral szürke, tûzköves mészkő és márga váltakozásából álló rétegcsoport következik (a Kendelbach Formáció Tiefengrabeni Tagozata). Ezen belül jelölték ki a triász-jura határt a Kuchjoch sztratotípus szelvényében. A Kendelbachi Formációt a sinemuri Adnéti Mészkő fedi (GAWLicK et al. 2009, HiLleBRANDT et al. 2013).

Az Északi-Mészkőalpok területének jelentős részét a késő-rhaetiben ismét karbonátplatformok foglalták el. A megfulladást követően a zátonyokkal szegélyezett platformok előtéri lejtőjére késő-hettangi, az Adnéti Formációcsoportba tartozó vörös gumós, hemipelágikus mészkő, míg a platformok tetején a Dachsteini Mészkő zátonyképződményeire üledékhézaggal crinoideás mészkő ("Hierlatzbasiskalk") települt (BÖHM et al. 1999, Вӧнм 2003). Вӧнм et al. (1999) értelmezése szerint a megfulladást a rhaeti legvégén feltehetően szárazra kerüléshez köthető erózió előzhette meg, és ezt követte a triász-jura határkrízissel egy időben indult vízszintemelkedés, amellyel a lecsökkent karbonátprodukció nem tudott lépést tartani.

A Déli-Alpok nyugati részén (Lombardia) a noriban kialakult, gyorsan süllyedő medencékben a rhaetiben humiddá váló klímán szerves anyagban gazdag, agyagos kőzetek (Riva di Solto Formáció), majd a késő-rhaetiben márga és Megalodonféle kagylókat tartalmazó, sekélytengeri mészkô ciklusos váltakozásából felépülő rétegsorok (Zu Formáció) képződtek. A határ az erre következő, sötétszürke, vékonyréteges, márgával közberétegzett mészkő (Malanotte Formáció) bázisánál vonható meg (GALLI et al. 2007). Erre sekélytengeri, alsó részén ooidos, grainstone szövetú platformkarbonát-egység (Conchodon Dolomit Formáció) progradál.

A Lombard-medencétől keletre elhelyezkedő Velenceikarbonátplatformon a kora-jurában számottevően megváltozott a karbonátüledéket létrehozó ökológiai rendszer összetétele, de a platform megfulladása csak az aaleni elején következett be (COBIANCHI \& PicOTTI 2001). Az ettől nem messze található Trento-platform nyugati peremének kora-sinemuri 
megfulladását egy közeli vetőzóna aktivitásának tulajdonítják. A platform többi része szigetplatformként élt tovább (Picotti \& Cobianchi 1996, Cobianchi \& PicotTi 2001). A késô-pliensbachiban a szerkezeti mozgások hatására a platform kibillent (ZEMPOLICH 1993) és tengerszintcsökkenést követôen rámpává alakult (COBIANCHI \& PICOTTI 2001). Végső megfulladása csak a bajociban következett be (ZEMPOLICH 1993, CoBianchi \& PicotTi 2001). A Trento-platformtól a Belluno-árokkal elválasztott Friuli-platform a krétáig, sôt a kapcsolódó Adriai-Dinári-platform egészen a paleogénig fennmaradt (Bosellini et al. 1981, ČADJENOVIĆ et al. 2008).

Hasonló megfulladásos, üledékhézagos határ ismert a Dunántúli-középhegységben is, a Gerecse körzetében. A Dunántúli-középhegység délnyugati részén azonban a triászban indult platformépuilés a jurában is folytatódott. A riftesedést okozó extenzió, a tengerszintváltozások, a szénés a foszforciklusban, illetve a Pangea feldarabolódása következtében megváltozó áramlási rendszerekben bekövetkező óceanológiai változások, klimatikus és ökológiai események, kihalások valószínúleg együtt, egymással kölcsönhatásban okozhatták a platformok megfulladását (BICE \& Stewart 1990, Zempolich 1993, Cobianchi \& PicotTi 2001, BERNOULLI 2001).

\section{Kemosztratigráfia a triász-jura határ környékén}

Egyes tömeges kihalási események és szénizotóp-anomáliák időbeli egybeesését már az 1980-as években kimutatták, elsóként a kréta végi, majd a perm végi események kapcsán (HoLSER et al. 1996). A visszatérően jelentkező kapcsolat azt sejteti, hogy mindkét jelenség hátterében közös kiváltó okok, az élővilágot és a szénkörforgást átrendező gyors és nagyléptékú környezetváltozások állhatnak. A triász-jura határról a 2000-es évek elején sikerült csak meggyőzően igazolni a triász végi kihalással egyidős negatív szénizotóp-anomáliát: az áttörést hozó szelvények között a kanadai Queen Charlotte-szigetek (WARD et al. 2001) és angliai St Audrie's-öböl (Hesselbo et al. 2002) mellett a csôvári Vár-hegy szelvénye is fontos adatokkal szolgált (PÁLFY et al. 2001). Mindhárom szelvényben jelentkezik — közvetlenül a triász-jura határ alatt — egy éles és rövid negatív szénizotóp-anomália, amit az angliai szelvényben egy, fő szénizotóp-anomáliának nevezett, elnyújtott kilengés követ az alsó-hettangiban. Az elmúlt 15 évben több tucat szelvényt vizsgáltak világszerte, melyek alapján mára a triász-jura határ körüli szénizotóp-anomáliák léte igazoltnak tekinthető, de a képet helyi és regionális eltérések és az elsőként leírt egyszerú mintázatnál összetettebb lefutású görbék bonyolítják. Az ellentmondások feloldása fontos célkitűzés, hiszen a szénizotóp-anomáliák a rétegtani korreláció fontos eszközévé váltak (LINDSTRÖM et al. 2017). Tisztázásra vár többek között az egyes rhaeti szelvényekben felismert „előfutár” anomália (RUHL \& KÜRSCHNER 2011) reprodukálhatósága, a hettangi különböző szintjeiben helyenként kimutatott markáns pozitív anomáliák mibenléte
(Williford et al. 2007, vAN DE SchootbrugGe et al. 2008), illetve az egyes szerzők által a hosszan tartó perturbáció jelének tartott, a fő anomáliák között látszólag megjelenó kisebb anomáliák valódisága (BARTOLINI et al. 2012, LinDSTRÖM et al. 2017).

A csôvári Vár-hegy szelvényének jelentősége nem csak abban áll, hogy az elsôk közé tartozott a triász végi szénizotóp-anomália kimutatásában, hanem az elsô olyan adatsort is szolgáltatta, amely a karbonátban $\left({ }^{13} \mathrm{C}_{\mathrm{karb}}\right)$ és a szerves anyagban ${ }^{13} \mathrm{C}_{\text {org }}$ ) egyaránt, párhuzamosan jelezte a $-3,5 \%$, illetve $-2 \%$, mértékú eltolódást a biosztratigráfiai korlátokkal azonosított határintervallum mintegy 2 m vastag szakaszán (PÁLFY et al. 2001). A karbonátot ért mérsékelt diagenetikus felülírás okozta zaj ellenére a két görbe nagyfokú hasonlósága megerôsíti az anomália elsődleges jelként való értelmezését. Ezt támogatja az is, hogy a ${ }^{13} \mathrm{C}_{\text {org }}$ nem korrelál sem a teljes szervesanyag-tartalom, sem a hidrogénindex változásaival. A nagy negatív kilengés a kezdeti szénizotóp-anomáliával, egy kisebb negatív anomália a rhaetiben pedig az „előfutár” anomáliával párhuzamosítható. A fő negatív anomáliának megfeleltethetô eltolódást ezzel szemben a későbbi, a vizsgált szelvényszakaszt fölfelé további 20 m-rel, a középső-hettangiig bôvítő kutatás sem talált, viszont a markáns kezdeti anomália megnövelt felbontású vizsgálatával rövidtávú oszcillációk sorozatát tárta fel (PÁLFY et al. 2007a). A Vár-heggyel átellenben a pokol-völgyi kőfejtô $16 \mathrm{~m}$ vastag felsô rhaeti rétegsorát KORTE \& KOZUR (2011) vizsgálták, és bár egy enyhe, $1 \%$ o körüli negatív eltolódást és az azt lépcsőzetesen követő 2\%o-es pozitív eltolódást regisztráltak, ezek megfeleltethetôsége a vár-hegyi szelvénnyel nem egyértelmú. A szénizotóp-adatokon kívül a pokol-völgyi kőfejtő rhaeti conodontáin mért ${ }^{87} \mathrm{Sr}-{ }^{86} \mathrm{Sr}$ adatok hozzájárultak a Sr-izotópsztratigráfia referenciagörbéje triász végi szakaszának kalibrálásához (KORTE 1999, KORTE et al. 2003).

Összességében, egyrészt a triász-jura átmenet szénizotóp-anomáliái fontos szerepet játszanak a rétegtani korrelációban, aminek jelentôségét tovább növeli a közelmúltban az ausztriai Kuhjoch szelvényében kijelölt GSSP (HillebrandT et al. 2013) részletesen tanulmányozott szénizotóp-sztratigráfiája (RuHL et al. 2009). Másrészt az üledékes rétegsorokban megőrződött szénizotóp-összetételbeli változások a szénkörforgás zavarait jelzik, a légkör, az óceán, a bioszféra és a litoszféra szorosan összekapcsolt alrendszereinek az egyensúlyi állapotból való kizökkenése révén. Ezek összefüggéseinek feltárása intenzíven folyik, a triász-jura határ körüli események láncolatának jobb megértése reményében. További magyarországi triász-jura határszelvények kemosztratigráfiai vizsgálata is folyamatban van (KovÁCS 2016).

\section{A triász végi kihalás és a környezeti változások lehetséges okai}

A triász végi, a fanerozoikum ,öt nagy” tömeges kihalása között a folyamatait és okait tekintve sokáig a kevésbé 
feltártak közé tartozott, amiben az időről időre megjelent áttekintő tanulmányok is egyetértettek (pl. HALLAM 1990, 2002, TANNER et al. 2004). A részben magyar kezdeményezésre és vezetéssel 2001-2005 között zajlott IGCP 458 projekt során (HESSELBO et al. 2007) és az azóta eltelt időben azonban mind több kérdésre formálódik válasz, ha nem is érve még el a kutatói közösség teljes konszenzusát (PÁLFY \& Kocsis 2014).

A triász-jura határ tengeri rétegsorait számos helyen szakítja meg üledékhézag, ami miatt korán felmerült a kihalások oknyomozásában egykor leggyakrabban hangoztatott érv, a hirtelen tengerszintváltozások, azaz gyors egymásutánban zajló regresszió-transzgresszió páros lehetősége (HALLAM \& WigNALL 1999), ahol az utóbbi hozzájárulhatott a tengerfenéki anoxikus vízréteg kialakulásához is (WIGNALL \& BoND 2008). Bár a hettangiban az epikontinentális tengerekben sokfelé rakódtak le anoxikus aljzatra utaló üledékek (VAN DE SchOOTBRUGGE et al. 2013), sőt biomarkerek a fotikus zónát is elérő anoxiára is utalnak (RICHOZ et al. 2012), közvetlenül a triász-jura határ közelében csak helyi jelentôséggel és korlátozott elterjedésben ismertek szerves anyagban gazdag üledékes képződmények (BoNIs et al. 2010b). Ennél meggyőzőbbek a számos tanulmány által szolgáltatott bizonyítékok a határ körüli gyors klímaváltozásra. Lehúlést a légkörbe kerülő $\mathrm{SO}_{2}$-ből képződő szulfátaeroszolok indíthatnak el, amire geokémiai (VAN DE SCHOOTBRUGGE et al. 2009) és paleobotanikai adatok is utalnak (BACON et al. 2013). Még nagyobb jelentősége van a gyors és nagymértékú $\mathrm{CO}_{2}$-növekedés vezérelte felmelegedésnek (McELWAIN et al. 1999, SCHALLER et al. 2011). A légkörból a tengerbe oldódó $\mathrm{CO}_{2}$ óceánsavasodáshoz vezetett, ami krízist okozott a mészvázú szervezetek sorában és a karbonátképződésben (HAUTMANN 2004), melyet egyre több bizonyíték támaszt alá (GreEnE et al. 2012). HuYnH \& POulsen kíséreletei azt mutatták, hogy a légköri $\mathrm{CO}_{2}$ négyszeres növekedése gyakori száraz, meleg napokhoz, intenzív hőingadozáshoz, továbbá az óceánokban vízrétegződés kialakulásához vezet (HUYNH \& POULSEN 2005), ily módon mind a szárazföldi, mind a tengeri élővilágra hatással van.

Míg az itt felsorolt környezetváltozásokat a triász végi kihalás közvetlen kiváltó okainak tekintik és szerepükről, egyenként vagy különböző kombinációkban, élénk vita folyik, az ezekhez vezető távolabbi okok tisztázására is sok kutatás irányult. A kréta végi kihalást égitest-becsapódással magyarázó Alvarez-hipotézis sikerén felbuzdulva a triász végi kihaláshoz is keresték és megtalálni vélték az impaktra utaló bizonyítékokat (OLSEN et al. 2002). Az irídiumanomália nagysága azonban nem meggyőző, a Newark-medencén kívül megbízhatóan reprodukálni pedig nem sikerült, mindössze egy szintén szerény dúsulást jelentettek Japán egy mélytengeri rétegsorából (HoRI et al. 2007). Annál inkább sikeresnek bizonyult az a kutatási vonal, ami nagy magmás provincia vulkáni tevékenységét jelöli meg a környezetváltozások láncolatát kiváltó oknak. MARzOLI et al. (1999) kormeghatározásai mutattak rá a Közép-Atlanti magmás provincia (KAMP) hatalmas kiterjedésére, ami a tengeri rétegsorokban definiált triász-jura határ korával jó egyezést mutatott (PÁLFY et al. 2000). A mind pontosabbá váló U-Pb kormeghatározások megerősítették a tengeri kihalás (SCHOENE et al. 2010) és a vulkanizmus (BLACKBURN et al. 2013) időbeli egyezését. A vulkáni kigázosodás mértékét újszerû geokémiai vizsgálatok is alátámasztják (CALlEGARO et al. 2014), valamint a légköri szén-dioxid szintjének megugrását is mind megbízhatóbban ismerjük (STEINTHORSDOTTIR et al. 2011). A vulkanizmus klímára gyakorolt hatása azért lehetett jelentős, mert egyrészt hirtelen indult meg, másrészt egyenlítő-közeli pozíciója a felszínre került hatalmas mennyiségú bazalt gyors mállását eredményezte (COHEN \& CoE 2007). Az éghajlatmódosító gázok nem csak közvetlenül eredtek a KAMP kigázosodásából és a felszínre került kőzetek mállásából. Emellett a tengeraljzati üledékben csapdázódott metán-hidrátnak a fokozatos felmelegedéstôl beinduló disszociációjából (BEERLING \& BERNER 2002), illetve a szervesanyag-tartalmú üledékes kőzetekbe nyomuló szubvulkáni intrúziók révén képződő termogén metánból (DAVIES et al. 2017), illetve ezek légköri oxidációjakor keletkező szén-dioxidból vezethető le a szuperüvegház-felmelegedés szcenáriója. Ennek legmarkánsabb geokémiai bizonyítékai a negatív szénizotóp-anomáliák. A KAMP és a kihalás egyidejúségét pedig az Északi-Mészkőalpok egy tengeri rétegsorában közvetlenül, vulkáni eredetú agyagásványok, és vulkáni porból hullott szferulák és mafikus ásványok segítségével is lehetett igazolni (PÁlfy \& ZAJZON 2012).

A triász végi kihalás és környezetváltozás jelenségegyüttese tehát jól értelmezhető a KAMP vulkanizmusa által kiváltott globális légköri, óceáni és élővilágbeli változások láncolataként. Ezzel beleillik a nagy magmás provinciákhoz kapcsolódó, vulkanizmus által kiváltott környezeti krízisek és tömeges kihalások sorozatába. A magmatizmus és a kihalás közötti ok-okozati kapcsolat, melyet először az időbeli egybeesésük alapján valószínúsítettek (COURTILLOT \& RENNE 2003), egyre több esettanulmány alapján olyan általános érvényú modellnek bizonyult (WIGNALL 2001), melyet sokrétú kutatások mind jobban megerôsítettek (BOND \& GRASBY 2017). A hazai vizsgálatok rámutattak, hogy a globális változások nyomait a magyarországi rétegsorok is magukban hordozzák.

\section{Magyarországi határszelvények}

Magyarország területén is találhatók olyan rétegsorok, amelyek magukban foglalják a triász-jura határintervallumot (1. ábra, A). Ezek közül a Dunántúli-középhegységi szerkezeti egység ÉK-i részén, a Csővár melletti Vár-hegyen feltárt szelvény nemzetközileg is jelentôs, különböző szempontok szerint, számos módszer alkalmazásával részletesen vizsgált és az eredményekről jelentős számú publikáció született. A Dunántúli-középhegységi-egység azért is kiemelkedő jelentőségú a triász-jura határ tekintetében, mert az egységen belül a határ merőben különböző őskörnyezeti tartományokat képviselő rétegsorokban ismert. Míg a csôvári szelvény platform előtéri lejtő és medence környezetet, a 


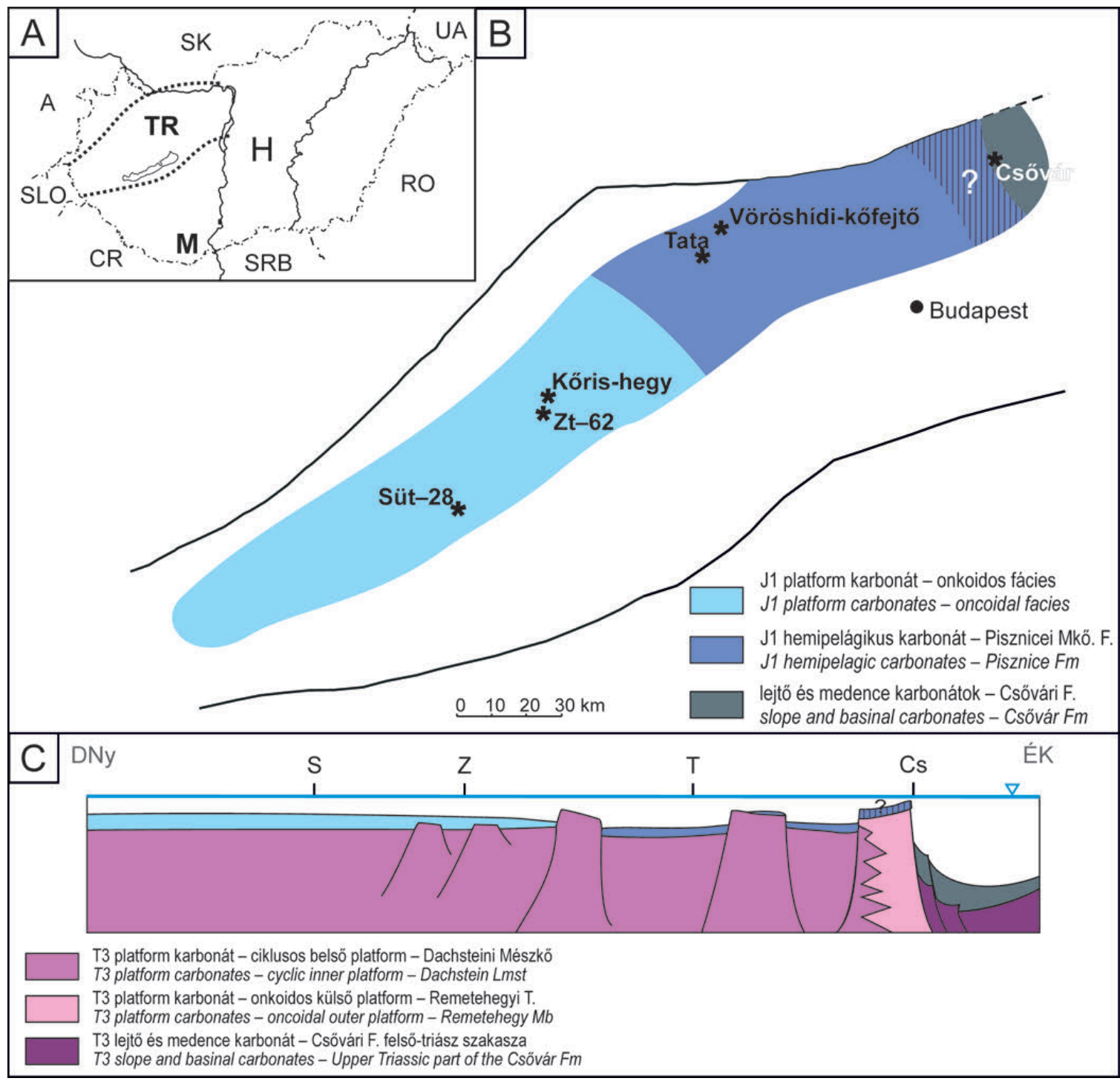

1. ábra. A) A cikkben emlitett magyarországi triász-jura határszelvények földrajzi helyzete. TR = Dunántúli-középhegység, M = Mecsek. B) A Dunántúli-középhegység késő-hettangi környezeti egységeit bemutató ősföldrajzi vázlat, a legfontosabb határszelvények helyzetének feltün_tetésével. C) A legfelső triász és legalsó jura formációkat és a késő-hettangi üledékképződési környezeteket bemutató elvi szelvény. S = Süt28 fúrás, $\mathrm{Z}=\mathrm{Zt}-62$ fúrás, $\mathrm{T}=$ Tata, $\mathrm{Cs}=$ Csővár

Figure 1. A) Geographic position of the Hungarian Triassic-Jurassic boundary sections referred to in the present paper. TR $=$ Transdanubian Range, $M$ = Mecsek Mountains, B) Palaeogeographic reconstruction showing the Late Hettangian environmental units within the Transdanubian Range Unit and the position of the most important boundary sections. C) Conceptual cross-section displaying the uppermost Triassic and the lowermost Jurassic formations and the Late Hettangian depositional environments. $S=$ Süt -28 borehole, $Z=Z t-62$ borehole, $T=T a t a, C S=C s o ̋ r a ́ r$

Gerecse szelvényei a triász Dachsteini platform tektonikusan tagolódó, majd megfulladó külsô részét, a bakonyi határszelvények pedig a platform belsejének a jura korai szakaszában is platformként továbbélố részét reprezentálják (1. ábra, $B$, $C)$. A triász időszak végén a Dunántúli-középhegységi-egység a Neotethys-óceán peremén létrejött széles karbonátplatformon helyezkedett el. A Tiszai-egység Mecseki-zónája az addigra erôsen lepusztult variszkuszi hegységvonulatok déli elôterében helyezkedett el, ahol egy gyorsan süllyedő medencében, a késő-triászban, majd a kora-jura kezdetén folyóvízi, delta, majd tengerparti lápi környezetben kőszénrétegekkel tagolt sziliciklasztos üledékek rakódtak le. A Mecsekben tehát a triász-jura határán lezajlott környezeti krízis szárazföldi-tengerparti környezetben megő́rződött nyomait lehet fellelni. E rétegsorok felszíni előfordulásai sajnos ma már csak korlátozottan hozzáférhetók, de a közelmúltban a határintervallum tanulmányozása céljából két komlói kőszénkutató fúrás ( $\mathrm{K}-137$ és $\mathrm{K}-176)$ rétegsorának részletes vizsgálatára nyílt lehetôség (RUCKWIED et al. 2008). Az eddigi vizsgálatok szerint a mikroflóraegyüttesben, akárcsak a makroflórában, nem volt egyértelmúen kimutatható tömeges kihalás (RUCKWIED et al. 2008, BARBACKA et al. 2017).

\section{Csôvár}

A csővári Vár-hegy déli lejtője ma már a triász-jura határ nemzetközileg is számon tartott szelvénye (2. ábra). A 


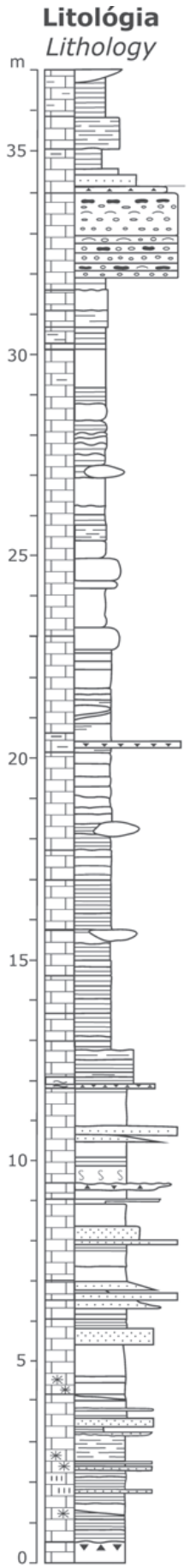

Biosztratigráfia
Biostratigraphy
Kemosztratigráfia

Chemostratigraphy

$\begin{array}{cc}\begin{array}{c}\text { radiolaria, } \\ \text { foraminifera, }\end{array} & \begin{array}{c}\text { ammonitesz, } \\ \text { konodonta }\end{array} \\ \text { palinomorfa } & \text { ammonoids, } \\ \text { radiolarians, } & \text { conodonts }\end{array}$

foraminifera,

palynomorphs

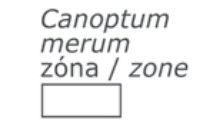

T utolsó

rhaet

palinomorfák

LO of

Rhaetian

palynomorphs

T utolsó

triász

LO of

Lriassic

foraminifera

${ }^{13} \mathrm{C}_{\text {carb }}(\%) \quad \delta^{13} \mathrm{C}_{\text {org }}(\%)$
Kor

Age

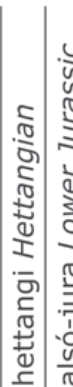

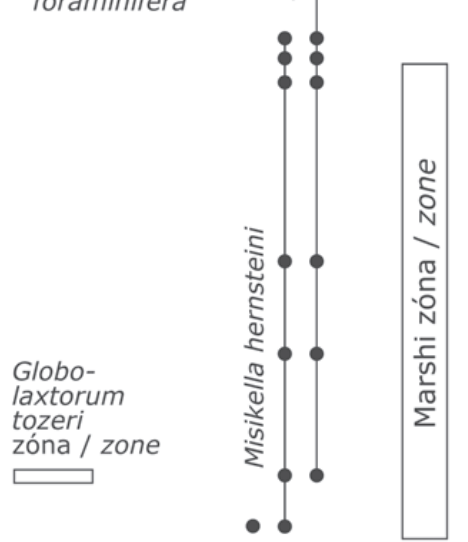
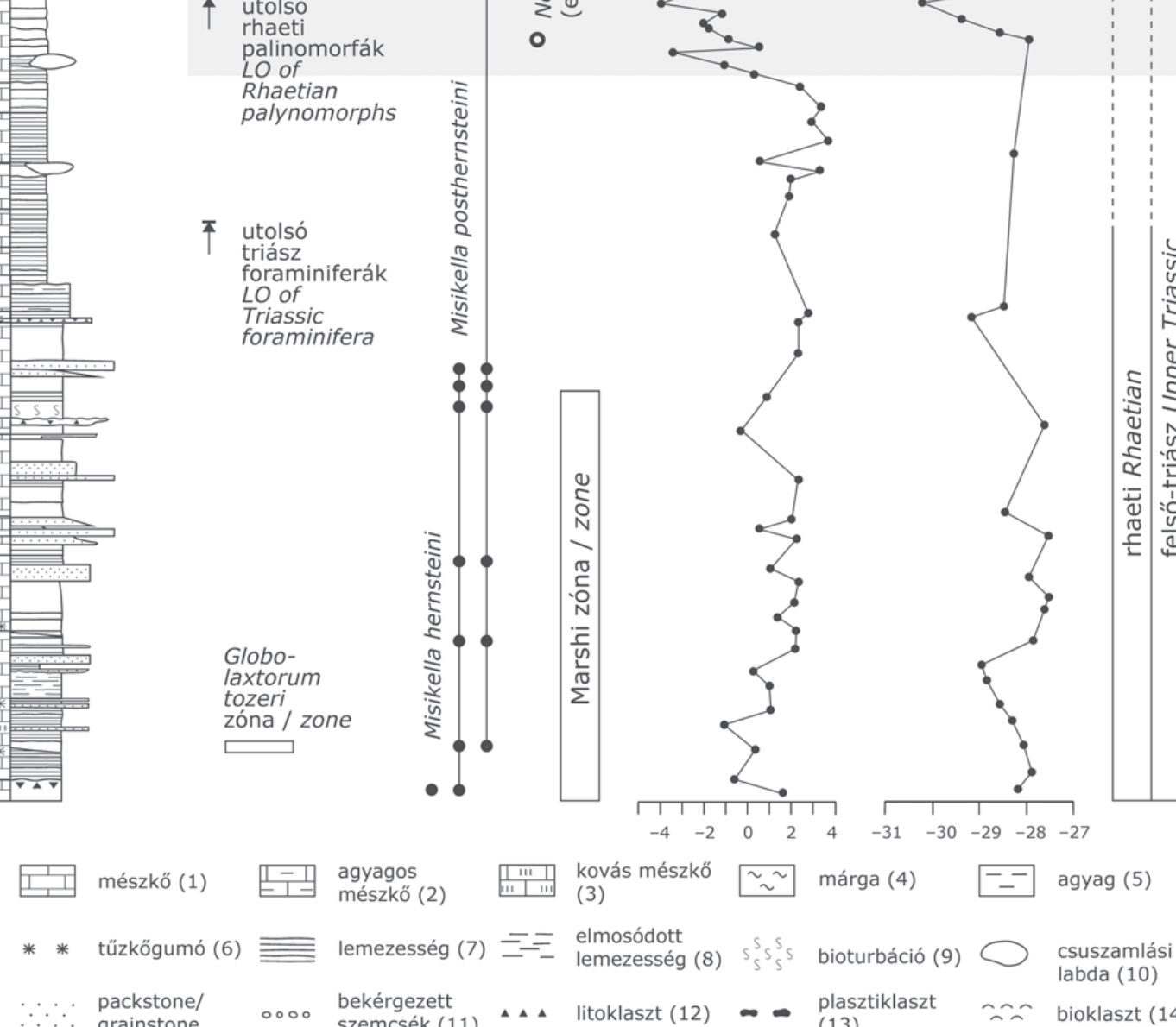
mészkő (2)

IIIII kovás mészkô (3)

$\sim \sim$ márga (4)

--- agyag (5)

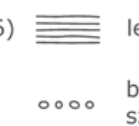
lemezesség (7) - $=$ elmosódott bekérgezett
szemcsék (11)
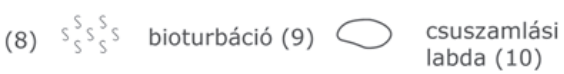

plasztiklaszt 乞乞 bioklaszt (14) (13)

2. ábra A csővári Vár-hegy triász-jura határszelvényének rétegsora és a fontosabb korjelző ősmaradványok elterjedésére alapozott bio- és kronosztratigráfiai besorolása, a szénizotópgörbe feltüntetésével. A triász-jura határintervallumban a markáns negatív szénizotóp-anomália szintjét szürke sáv jelöli (PÁLFY et al. 2001, 2007 és GöTZ et al. 2009 nyomán).

Figure 2. Integrated bio-, chrono- and carbon isotope chemostratigraphy of the Triassic-Jurassic boundary section of the Vár-hegy (Castle Hill) at Csővár. The grey band marks the pronounced negative carbon isotope anomaly in the Triassic-Jurassic boundary interval (after PÁLFY et al. 2001, 2007 and GöTZ et al. 2009).

Legend: 1 - limestone, 2 - argillaceous limestone, 3 - siliceous limestone, 4 - marl, 5 - clay, 6 - chert nodules, 7 - lamination, 8 - obscured lamination, 9 - ioturbation, 10 - slump ball, 11: coated grains, 12 - lithoclasts, 13 - plasticlasts, 14 - bioclasts 
Pokol-völgy talpától a várromig természetes kibukkanásokban és az azokat összekötő mesterséges árkolásban a legfelső triász-alsó-jura rétegsor többé-kevésbé folyamatosan vizsgálható. A feltárások a Csővári Mészkő Formáció felső szakaszát képviselik, amelyet korábban triász korúnak tartottak (VADÁsz 1910, Detre 1981, BALOGH 1981). A formáció magasabb részének kora-jura voltát először KozUR (1993) mutatta ki radiolariák alapján.

A Csôvári Mészkő Formációnak a határintervallumot magában foglaló felsőbb része proximális és disztális lejtőlábi, illetve medenceüledékként rakódott le (HAAs et al. 1997). A gyakori üledékcsuszamlásos szerkezetek a lejtő menti üledékmozgás bizonyítékai. A proximális turbiditnek értelmezett rétegkötegek alsó része uralkodóan crinoidea váztöredékből álló gradált kalkarenitből épül fel, ami fölfelé kalkarenitbe és kalcilutitba megy át. A lemezes szerkezetet mutató disztális turbiditciklusok kalkaleurit- és kalcilutitlemezek váltakozásából állnak. A turbidites rétegek karbonátszemcséket és mésziszapot tartalmazó zagyárakból, intraplatform medencében ülepedhettek le (HAAS \& TARDYFILÁCZ 2004). A turbiditek között radiolariás és szivacstús, medence fáciesű rétegek találhatók. A méteres nagyságrendû ciklicitást mutató fáciesváltozások orbitális meghatározottságú, valószínúleg excentricitási ciklusokhoz köthető, eusztatikus vízszintingadozásokat jeleznek (HAAs et al. 2010).

A Vár-hegy déli oldalában szelvény szerinti mikro- és makrofauna-gyújtés és integrált sztratigráfiai vizsgálatok történtek (PÁLFY et al. 2001, 2007a). A szórványosan előforduló ammoniteszek közül a Nevadaphyllites, Psiloceras és Waehneroceras szukcessziója jelzi a hettangi emelet alsó két standard zónáját, a Planorbis és Liasicus zónákat. A radiolaria-fauna újravizsgálatát DoszTÁlY L., majd OzSvÁRT P. végezte, kimutatva a legalsó hettangi Canoptum merum zónát. KozUR \& Mock (1991) Neohindeodella detrei néven új, legidősebb jura korúnak tartott conodonta fajt írt le a formáció Choristoceras fajjal igazolt felső-triász és a fent említett radiolariákkal datált alsó-jura közötti átmeneti részéből. A triász-jura határ helyzetét alulról a Misikella conodonta nemzetség fajainak (hersteini, posthersteini, ultima) egymás utáni eltúnésével jellemezhetjük (PÁLFY et al. 2007a). A határ megvonásában segítséget nyújt a triászra jellemző Aulotortus foraminiferafajok és Rhaetipollis germanicus, ill. Riccisporites tuberculatus pollenfajok kimaradása, majd a jurára utaló Involutina liassica foraminifera fellépése (GöRÖG in PÁLFY et al. 2007a, GöTZ et al. 2009).

A Choristoceras és Misikella tartalmú, legfelső-triász (felsô-rhaeti) rétegek és a legmélyebb helyzetú hettangi radiolariák között mintegy $5 \mathrm{~m}$, folyamatosnak látszó lejtőlábi és medence fáciesú rétegsor települ, amelyből diagnosztikus ősmaradvány nem került elő. Közvetlenül e szint alatt, karbonátban és szerves anyagban is mért markáns negatív ${ }^{13} \mathrm{C}$ csúcs jelentkezik, amely megbízható kemosztratigráfiai korrelációt tesz lehetővé a közvetlenül a rhaeti-hettangi határ alatt világszerte kimutatott és a triászjura határ ismérveként tekintett szénizotóp-anomáliával. A triász végi eseménnyel való korrelációt a sporomorpha vizs- gálatok által jelzett, egyidejû spóra és Prasinophyta alga felszaporodás is megerősíti (GöTz et al. 2009).

A csővári szelvény olyan szempontból is kiemelkedő jelentőségú, hogy ősföldrajzi helyzete miatt (platformelőtéri lejtő és hemipelágikus medence) lehetőséget kínál a sekélytengeri és a pelágikus fosszíliák együttes megjelenésére, és ezáltal biosztratigráfiai korrelációjukra, ami más módszerekkel szinte megoldhatatlan problémát jelent. Ezen túlmenően a palinológiai vizsgálatok lehetôséget teremtettek a szárazföldi és a tengeri fosszíliákon alapuló biosztratigráfia-beosztások közvetlen összevetésére is. A viszonylag közelről származtatható sporomorphák és szárazföldről származó fitoklasztok kimutatása a határintervallumban a platform egyes, kiemeltebb helyzetû részeinek szárazra kerülését is bizonyítja (HAAs et al. 2010).

\section{Tata, Gerecse}

A Gerecse hegység területén, a Vöröshídi-kőfejtőben, valamint a tatai Kálvária-dombon tárul fel laterálisan is nyomozható kiterjedésben a triász és a jura képződmények részletesen vizsgált határa. Mindkét szelvényben a platform környezetben képződött Dachsteini Mészkőre éles határral hemipelágikus Pisznicei Mészkő települ (FüLöP 1975, MindSZENTY 1992, HAAs 1995), azaz megfulladási rétegsort látunk. Tatán a jura rétegsor (3. ábra, A) néhány deciméter vastagságú, halvány rózsaszín, crinoideás wackestone szövetú mészkőpaddal kezdődik, amire centiméteres onkoidszemcséket, mikrobás kéreggel bevont brachiopodákat és ammoniteszeket is tartalmazó pad következik (MINDSZENTY 1992, HAAs 1995). Ammoniteszek alapján a legalsó rétegek kora középső-késő-hettangi (PÁLFY et al. 2007b), a jura rétegsor tehát jelentôs, több millió éves üledékhézaggal települ a felső-triász, rhaeti korú mészkő erodált felszínére. A hátságperemi és medence környezetben lerakódó folyamatos jura előfordulások néhány millió éves hézagaival szemben a Gerecse nyugati részének hátsági, hézagos rétegsoraiban esetenként a malm rétegek települnek közvetlenül a triászra (VIGH 1935).

A triász összlet legfelső és a jura rétegsor legalsó része számos oldódási, repedésképződési és cementációs esemény nyomait őrzi (3. ábra A, és 4. ábra, A, B). A kálváriadombi felső-triász mészkőben megjelenő kisebb pórusok és üregek ciklikus szárazra kerülés során képződtek, a részletes petrográfiai, ásványtani és geokémiai vizsgálatok tanúsága szerint (MINDSZENTY 1992, GYŐRI 2014). A tengerszintesést követően, a tengeri ősmaradványok (Megalodon-féle kagylók és foraminiferák) aragonitváza a felszín közelében kioldódott, biomold üregeket hagyva hátra. Az alacsony tengerszintû periódusokban az üledék felszínét peritidális környezetben mikrobás szövedék borította be, melynek felszínközeli diagenezise során fenesztrális pórusok jöttek létre. A ciklusokat elválasztó diszkonformitási felszínekhez köthető meteorikus lencsében kisebb, szabálytalan alakú üregek alakultak ki.

A jura bázisrétege Tatán nagyon kis szögben (1-2º met- 


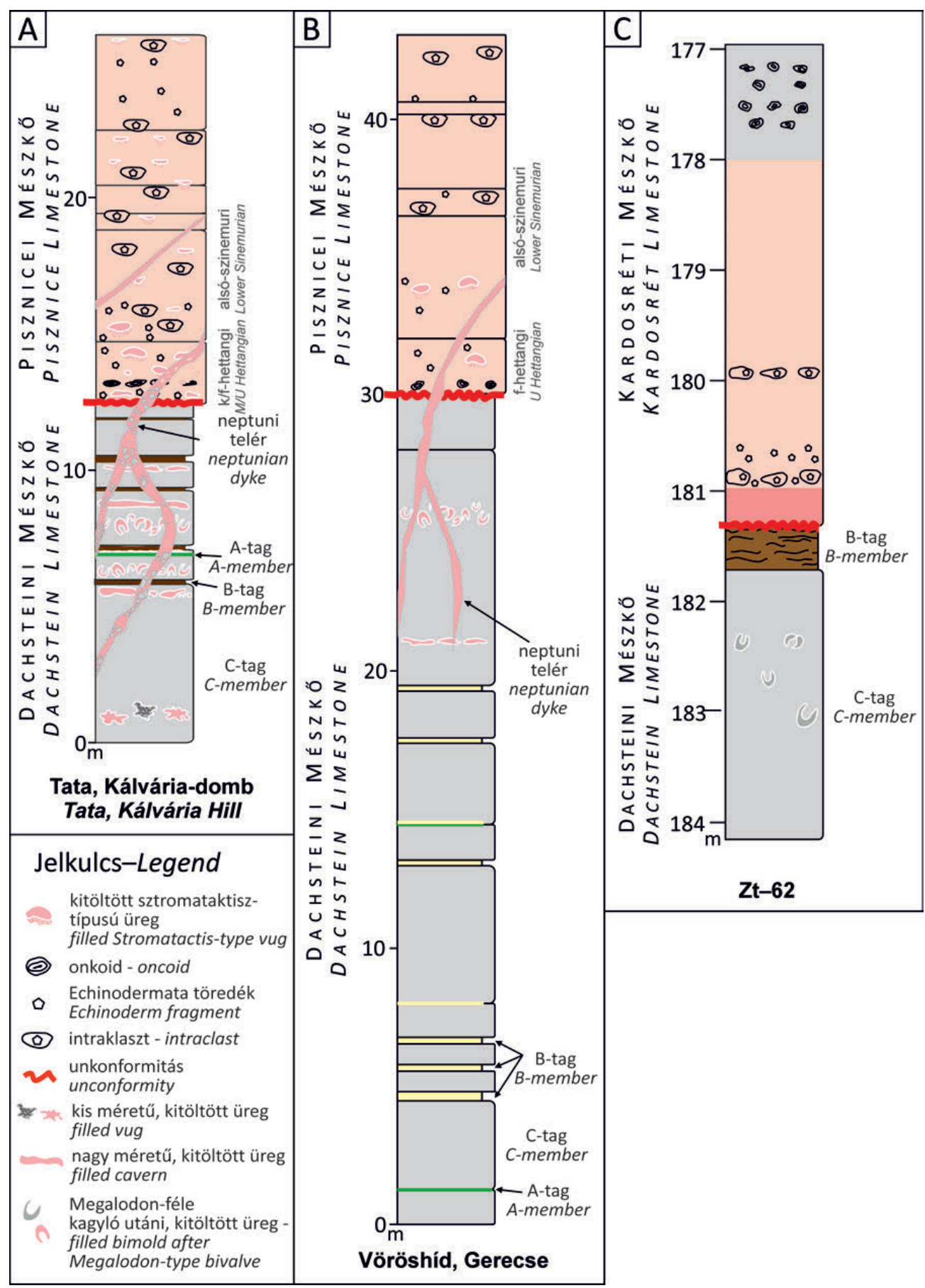

3. ábra A) A triász-jura határt magában foglaló rétegsor a tatai Kálvária-dombon. B) A triász-jura határt magában foglaló rétegsor a Vöröshídi-kőfejtőben, C) A triász-jura határt magában foglaló rétegsor a Zirc Zt-62 számú fúrásban

Figure 3. A) The Triassic-Jurassic boundary interval in the section of Tata, Kálvária Hill, B) The Triassic-Jurassic boundaryinterval in the Vöröshíd Quarry, C) The Triassic-Jurassic boundary interval at Zirc in core Zt-62

szi a fekü Dachsteini Mészkő felszínét. A nagy kiterjedésű kőfejtőben a Dachsteini Mészkő rétegeinek azonosítása a határfelület mentén 1,3 m-es szintbeli különbség felismerését tette lehetôvé (HAAs 1995). Mindez a platform mészkő kőzetté válását követő igen kisfokú kibillenését és emiatt egyenlőtlen erózióját jelenti a megfulladást megelőzően. Feltételezhetô tehát, hogy legalábbis ezen a területen, a triász-jura határ közelében a platform rövid időre szárazulatra került (MindSZENTY 1992, LANTOS 2004, GYŐRI 2014). A meteorikus lencse kitüntetett felszínein (a vadózus és freatikus zóna határán, valamint az édesvízés a sós víz határán) ható oldódás nagyobb, több méter széles, elnyúlt üregeket hozott létre (3 ábra, A). A kitettség egyéb nyomait a szárazulati epizódot követô transzgressziós esemény eltüntette: az üregek falán izopach, szálas tengeri kalcitcement vált ki, az üledék/ kőzetfelszínt pedig szubmarin erózió alakította. 
Az extenziós tektonika felerôsödését jelzi a neptuni telérek (3. ábra, A és 4. ábra, C) megjelenése a hettangisinemuri során (LANTOS 2004). Ezek mentén a felső-triász kôzetben lévő üregek vörös mikrittel töltődtek fel, ami rész- ben a legidôsebb jura üledékből származik (LANTOs 2004). A kora-jurában folytatódó tektonikai aktivitás epizodikusan felerősödô jellegéről (a neptuni telérek mellett) az alsó-jura rétegekben megfigyelt sztromataktisz-típusú üregek is ta-
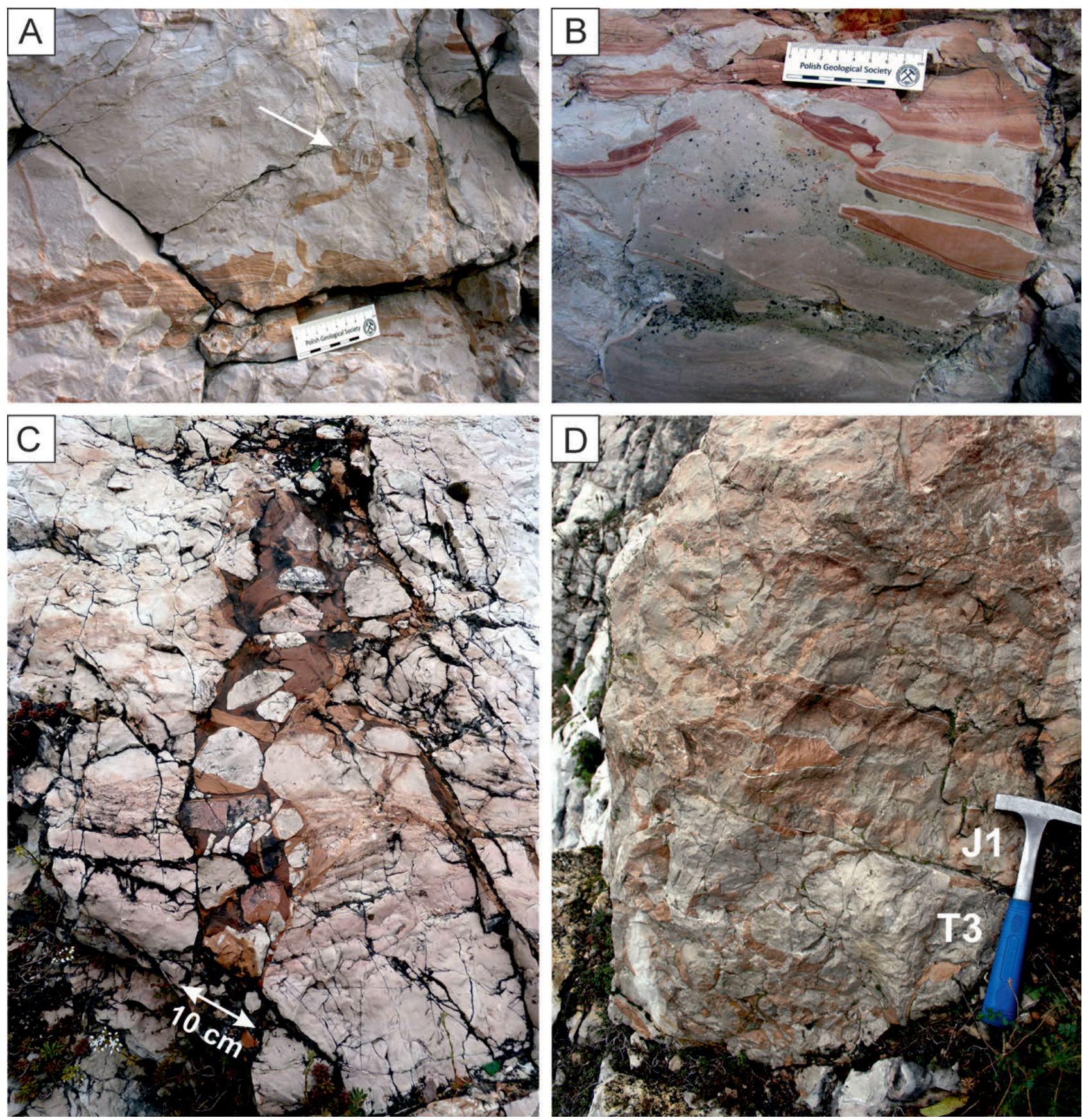

4. ábra. Üledékföldtani bélyegek a triász-jura határ közelében, a gerecsei karbonátos rétegsorokban. A) Megalodon-féle kagylók utáni (nyillal jelölt) és hosszabb elnyúlt üregek a felsö-triász Dachsteini Mészkőben, izopach, szálas kalcitkéreggel és többgenerációs, rózsaszín, vékonylemezes mikrittel kitöltve (Tata, Kálváriadomb). B) Szabálytalan alakú, oldott üregek a Dachsteini Mészkőben, izopach, szálas kalcittal és többgenerációs rózsaszín-vörös, vékonylemezes mikrittel kitöltve (Tata, Kálvária-domb). C) Neptuni telér Dachsteini Mészkőben, melynek kitöltése vörös mikrit mátrixban megjelenő felső-triász és alsó-jura mészkőklasztok (Tata, Kálvária-domb). D) A felső-triász és alsó-jura kőzetek határa a Gerecse Vöröshídi-kőfejtőjében, Megalodon-féle kagylók utáni üregek az előbbi, szabálytalan, oldott üregek az utóbbi kőzetben, mindkettőben vékonyabb izopach, szálas kalcit és rózsaszín mikrit kitöltés

Figure 4. Sedimentary features in carbonate strata near the Triassic-Jurassic boundary from the Gerecse Hills. A) Biomolds after Megalodon-type bivalves (marked by arrow) and vugs-cavities in the Upper Triassic Dachstein Limestone filled by isopachous fibrous calcite layer and multiple generation pink laminated micrite (Tata Kálvária Hill). B) Vugs in the Dachstein Limestone filled by isopachous fibrous calcite and multiple generation red laminated micrite - (Tata, Kálvária Hill). C) Neptunian dyke in Dachstein Limestone, filled by red micrite matrix and Upper Triassic and Lower Jurassic limestone clasts (Tata, Kálvária Hill). D) Boundary between the Upper Triassic and Lower Jurassic limestone in the Vöröshid Quarry, Gerecse Mts. Note the biomolds after Megalodontid bivalves in the Upper Triassic and the vugs in the Lower Jurassic limestone, both filled by thinner isopachous calcite layer and pink micrite 
núskodnak. Ezeket nem csak elmetszették és feltöltötték a neptuni telérek, mint a triász mészkőben megjelenő üregeket, de genetikai kapcsolatban is állhattak velük. A sztromataktisz-típusú üregek a telérek felsố elvégzôdési zónájában jöhettek létre, a még kevésbé litifikált üledékben (LANTOS 2004, GYŐRI 2014).

A szöveti jellegek és a bioklaszt- (elsôsorban crinoidea-) tartalom változásai, valamint a megfigyelt agyagközök alapján felismert üledékes ciklusok segítségével Tata, Tölgyhát és a tardosi Bánya-hegy medence összletei meglepően jól korrelálhatók voltak egymással. Hasonló rétegsor tárul fel a Tardos-Süttő közötti út menti Vöröshídi-kőfejtőben is (KoNDA, 1987). Itt is felismerhetőek a tatai triász-jura határ mentén megjelenő üreg-és telértípusok, de a feltételezhetően hosszabb szárazulati eseményhez köthető oldott üregek, valamint a szerkezetalakuláshoz és aljzati tagolódáshoz kapcsolódó neptuni telérek is kisebb számban és méretben jelennek meg itt (3. ábra, $B$ és 4. ábra, D).

\section{Bakony}

A Bakonyban a triász-jura határ platformkarbonát rétegsoron belül vonható meg. A lofer-ciklusos rhaeti Dachsteini Mészkő enyhén hullámos felszínére települ a ciklicitást már nem mutató Kardosréti Mészkô. Az ÉszakiBakonyban, Zirc mellett mélyített Zt-62 jelû fúrásban feltárt rétegsor tekinthető a jelenleg ismert legjobb határszelvénynek, amit kiegészít a Kőris-hegy felszíni szelvénye. A Déli-Bakonyban jellegében hasonló rétegsort tárt fel a sümegi Süt-28 jelú fúrás (HAAs et al. 1984). A rétegek meredek dőlése és a rétegsort sûrûn átszelő neptuni telérek miatt azonban ez a szelvény nem alkalmas a határ jellegének pontosabb felderítésére.

A Zt-62 jelû fúrásban (3. ábra, C) a Dachsteini Mészkő legfelső szakaszán 4-5 m vastagságú, Megalodon-féle kagylómaradványokat tartalmazó, a szubtidális zónában lerakódott mészkőpadok váltakoznak néhány deciméter vastagságú, árapályövi sztromatolitrétegekkel és ritkán a ciklusokat elválasztó hullámos határok fölötti, fekete brecscsát tartalmazó, vékony, szupratidális környezetben képződött rétegekkel. A legutolsó lofer-ciklus legfelső eleme $30 \mathrm{~cm}$-es sztromatolitréteg. Ennek felszíne enyhén hullámos eróziós felület, a karsztosodás minden nyoma nélkül. Erre 2 m vastagságban, rózsaszínú bioklasztos, peloidos wackestone szövetú mészkő települ, szivacstúkkel, ostracodákkal, crinoidea váztöredékkel. Erre világosszürke onkoidos, wackestone szövetû mészkő következik, egyes rétegekben szivacstúkkel, ami a Kardosréti Mészkő legjellemzőbb kifejlődésének tekinthetô. A peritidális környezetekben képződött kőzetfajták kimaradása a Kardosréti Mészkőben a lofer-ciklusos Dachsteini Mészkőnél mélyebb, de még a jól átvilágított övben folyó üledékképződést jelent, ahol a rövid időtartamú vízszintcsökkenések során sem alakult ki árapálysíksági környezet.

A Kőris-hegy szelvényében a Dachsteini Mészkő legfelső része szórványosan Megalodon-féle kagylókat tartal- maz, mikrofauna-tartalma szegényes (CsÁszÁR \& ORAVECZNÉ SCHEFFER 1987). A határ alatti rétegben a foraminifera-együttesben a Triasinák mellett agglutinált formák is találhatók és meglehetősen sok algamaradvány is. A határfelszínen jól megfigyelhető a bioerózió nyoma. Az azt fedô réteg onkoidos packstone szövetû, Involutina liassica foraminiferával.

A Kardosréti Mészkő korbesorolását nehezíti, hogy rétegeiből ammonitesz mindezidáig nem került elő, hettangi besorolását települési helyzete indokolja. Pontosabb korbesorolást a számos lelőhelyrôl feldolgozott brachiopoda fauna sem tett lehetôvé (Dulai 2002). A tafonómiai vizsgálatok azonban kimutatták, hogy a sinemuri-pliensbachi során markánsan jellemző, hátságokra és hátságok közötti medencékre tagolódó aljzatmintázat halványan már a hettangi során is jelentkezett. A kialakuló medenceterületeken 50-150 m-re becsült vastagságú képződmény (BENCE et al. 1990) lerakódása az aljzati különbségeket már nem tudta teljesen elfedni. Felfelé a Pisznicei Mészkőbe vékony, folyamatos átmenettel megy át, vagy éles határ mentén érintkezik. A fedő Pisznicei Mészkőből a Bakony területén nem ismert ősmaradvánnyal bizonyított hettangi korú előfordulás, bár a Lókúti-dombon BENCE et al. (1990) szerint kora felső-hettangi-alsó-sinemuri. Itt a határ felett 10 m-rel előkerült ammonitesz-fauna igazolta a kora-sinemuri kort (GÉCZY 1971, Dulai 2002).

\section{Összefoglalás}

A triász időszakot lezáró kihalási esemény egyike a fanerozoikumban kimutatott öt legnagyobb kihalási rátával jellemezhető tömeges kihalási eseménynek. A hatások elsősorban tengeri rétegsorokban mutathatók ki, a környezeti krízis feltehetôen elsősorban a tengeri ökoszisztémát károsíthatta. A szárazföldi élővilágban is felismerhetők jelentős környezetváltozás nyomai, de a hatás sokkal kevésbé látszik markánsnak.

Számos tengeri rétegsorban figyeltek meg számottevő litológiai változásokat a határ közelében. Ezek egy része trendszerú, más része ciklusos jellegú és vannak rövid idejû eseményeket tükröző változások is. Csak igen részletes elemzéssel deríthetô ki, hogy ezek a jelenségek tengerszintváltozásra, klímaváltozásra esetleg ezek együttes hatására vezethetôk-e vissza és, hogy összefüggésben vannak-e a tömeges kihalást eredményező környezeti krízissel.

A 2000-es évek elején sikerült igazolni a triász végi kihalással egyidejû negatív szénizotóp-anomáliát. Ez döntő jelentőségú a kronosztratigráfiai korreláció szempontjából, továbbá egyértelmúen jelzi a szénháztartás zavarait a Föld külső, egymással szoros kapcsolatban lévő szféráiban.

A jelenlegi ismeretek szerint, a triász végi környezeti krízis legvalószínúbb kiváltó oka a Közép-Atlanti magmás provincia hatalmas területre kiterjedő intenzív vulkanizmusa lehetett, ami globális légköri, óceáni és élővilágbeli változások láncolatát indíthatta el.

A triász-jura határon lejátszódott globális változások 
nyomai hazai szelvényekben is megőrződtek. Ezek közül a viszonylag mély tengermedencében lerakódott csővári szelvény nemzetközileg is kiemelkedő jelentőségû. A gerecsei és a bakonyi szelvények a sekély karbonátplatformok reagálásának lehetôségeit példázzák. A mecseki szelvények a tengermelléki-szárazföldi üledékgyújtôk határszelvényeinek kutatására adnak lehetôséget.

\section{Köszönetnyilvánítás}

Ez a dolgozat a MinDSZENTY Andrea professzor asszony 70. születésnapja alkalmából elhangzott előadásokból kiindulva készült, kifejezve a szerzők tiszteletét és nagyrabecsülését életmúve, azon belül a triász-jura határ kutatásában játszott szerepe iránt, és háláját a geológus nemzedékek számára átadott tudásáért és a szúnni nem akaró inspirációért. Ez a tanulmány az MTA-MTM-ELTE Paleontológiai Kutatócsoport 257. publikációja.

\section{Irodalom — References}

ALROY, J. 2008: Dynamics of origination and extinction in the marine fossil record. — PNAS 105/Supplement 1, 11536-11542. https://doi.org/10.1073/pnas.0802597105

Alroy, J. 2014: Accurate and precise estimates of origination and extinction rates. — Paleobiology 40/3, 374-397. https://doi.org/ $10.1666 / 13036$

Alvarez, L., Alvarez, W., AsARo, F. \& Michel, H. 1980: Extraterrestrial cause for the Cretaceous-Tertiary extinction. - Science 208, 1095-1108. https://doi.org/10.1126/science.208.4448.1095

Bacon, K. L., Belcher, C. M., Haworth, M. \& McElwain, J. C. 2013: Increased atmospheric $\mathrm{SO}_{2}$ detected from changes in leaf physiognomy across the Triassic-Jurassic boundary interval of East Greenland. - PLOS one 8/4, e60614. https://doi.org/10.1371/ journal.pone.0060614

BALOGH, K. 1981: Correlation of the Hungarian Triassic. — Acta Geologica Hungarica 24/1, 3-48.

Barbacka, M., PACYNA, G., Kocsis, Á. T., JARZYNKA, A., ZiAJA, J. \& BodOR, E. 2017: Changes in terrestrial floras at the Triassic-Jurassic Boundary in Europe. - Palaeogeography, Palaeoclimatology, Palaeoecology 480, 80-93. https://doi.org//10.1016/j.palaeo. 2017.05.024

Bartolini, A., Guex, J., Spangenberg, J., Schoene, B., Taylor, D., Schaltegger, U. \& Atudorei, V. 2012: Disentangling the Hettangian carbon isotope record: Implications for the aftermath of the end-Triassic mass extinction. - Geochemistry Geophysics Geosystems 13, Q01007. https://doi.org/10.1029/2011GC003807

BeErling, D. J. \& Berner, R. A. 2002: Biogeochemical constraints on the Triassic-Jurassic boundary carbon cycle event. — Global Biogeochemical Cycles 16/3, 10-36. https://doi.org/10.1029/2001gb001637

Bence G., Bernhardt B., Bihari D., Bálint Cs., Császár G., Gyalog L., HaAs J., Horváth I., Jámbor Á., Kaiser M., Kéri J., KóKay J., Konda J., Lelkesné F. Gy., Majoros Gy., Peregi Zs., Raincsák Gy., Solti G., Tóth Á., Tóth Gy. 1990: A Bakony hegység földtani képzódményei. Magyarázó a Bakony hegység fedetlen földtani térképéhez 1: 50 000. — Magyar Állami Földtani Intézet, Budapest pp. 119 p.

BERNOULLI, D. 2001: Mesozoic-Tertiary carbonate platforms, slopes and basins of the external Apennines and Sicily. — In: VAI, G. B. \& MartinI, I. P. (eds): Anatomy of an orogen: the Apennines and adjacent Mediterranean basins. Kluwer, Dordrecht, 307-326. https://doi.org/10.1007/978-94-015-9829-3_18

Bernoulli, D. \& Jenkyns, H. C. 1974: Alpine, Mediterranean and Central Atlantic Mesozoic facies in relation to the early evolution of the Tethys. - In. DotT, R. H. \& SHAVER, R. H (eds): Modern and ancient geosynclinal sedimentation. SEPM Special Publication 19, 129-187. https://doi.org/10.2110/pec.74.19.0129

Bertotti, G., Picotti, V., Bernoulli, D. \& CAstellarin, A. 1993: From rifting to drifting: tectonic evolution of the South-Alpine upper crust from the Triassic to the Early Cretaceous. — Sedimentary Geology 86/1, 53-76. https://doi.org/10.1016/0037-0738(93)90133$P$

BiCE D. M. \& STEWART K. G. 1990: The formation and drowning of isolated carbonate seamounts: tectonic and ecological controls in the northern Apennines. — IAS Special Publications 9, 145-168. https://doi.org/10.1002/9781444303834.ch6

Blackburn, T. J., Olsen, P. E., Bowring, S. A., Mclean, N. M., Kent, D. V., Puffer, J., Mchone, G., Rasbury, E. T. \& Et-Touhami, M. 2013: Zircon U-Pb geochronology links the end-Triassic extinction with the Central Atlantic Magmatic Province. - Science 340/6135, 941-945. https://doi.org/10.1126/science.1234204

Bond, D. P. G. \& GRASBY, S. E. 2017: On the causes of mass extinctions. - Palaeogeography, Palaeoclimatology, Palaeoecology 478, 3-29. https://doi.org/10.1016/j.palaeo.2016.11.005

Bonis, N. R., RUHL, M. \& KURSCHNER, W. M. 2010a: Milankovitch-scale palynological turnover across the Triassic-Jurassic transition at St. Audrie's Bay, SW UK. — Journal of the Geological Society 167/5, 877-888. https://doi.org/10.1144/0016-76492009-141

Bonis, N. R., RUHL, M. \& KuRschner, W. M. 2010b: Climate change driven black shale deposition during the end-Triassic in the western Tethys. - Palaeogeography Palaeoclimatology Palaeoecology 290/1-4, 151-159. https://doi.org/10.1016/j.palaeo.2009.06.016

Bosellini, A., MasetTi, D. \& SARTi, M. 1981: A Jurassic “Tongue of the Ocean” infilled with oolitic sands: The Belluno Trough, Venetian Alps, Italy. — Marine Geology 44/1, 59-95. https://doi.org/10.1016/0025-3227(81)90113-4

Bown, P., LEes, J. \& Young, J. 2004: Calcareous nannoplankton evolution and diversity through time. — In: THIERSTEIN, H. \& YounG, J. (eds): Coccolithophores. Springer, Berlin \& Heidelberg, 481508. https://doi.org/10.1007/978-3-662-06278-4_18 
BöHM, F. 2003: Lithostratigraphy of the Adnet Group (Lower to Middle Jurassic, Salzburg, Austria). — In: PILLER, W. E. (ed.): Stratigraphia Austriaca. Verlag der Österrischen Akademie der Wissenschaften, Wien, 231-268.

Böhm, F., Ebli, O., Krystyn, L., LobitZer, H., RAKÚs, M. \& Siblík, M. 1999: Fauna, stratigraphy and depositional environment of the Hettangian-Sinemurian (Early Jurassic) of Adnet (Salzburg, Österreich). — Abhandlungen der geologischen Bundesanstalt 56/2, 143-271.

Brayard, A., Escarguel, G., Bucher, H., Monnet, C., Bruhwiler, T., Goudemand, N., Galfetti, T. \& Guex, J. 2009: Good genes and good luck: Ammonoid diversity and the end-Permian mass extinction. — Science 325/5944, 1118-1121. https://doi.org/ 10.1126/science. 1174638

Brusatte, S. L., Benton, M. J., Ruta, M. \& Lloyd, G. T. 2008: Superiority, competition, and opportunism in the evolutionary radiation of dinosaurs. - Science 321/5895, 14851488. https://doi.org/10.1126/science.1161833

ČAdjenović, D., Kilibarda, Z. \& Radulović, N. 2008: Late Triassic to Late Jurassic evolution of the Adriatic Carbonate Platform and Budva Basin, Southern Montenegro. — Sedimentary Geology 204/1, 1-17. https://doi.org/10.1016/j.sedgeo.2007.12.005

Callegaro, S., Baker, D. R., De Min, A., Marzoli, A., Geraki, K., Bertrand, H., Viti, C. \& Nestola, F. 2014: Microanalyses link sulfur from large igneous provinces and Mesozoic mass extinctions. — Geology 42/10, 895-898. https://doi.org/10.1130/g35983.1

CIRILLI, S. 2010: Upper Triassic-lowermost Jurassic palynology and palynostratigraphy: A review. — In: LuCAs, S. G. (ed.): The Triassic timescale. Geological Society, London, Special Publications 334, The Geological Society Publishing House, Bath, $285-314$. https://doi.org/10.1144/sp334.12

Clémence, M.-E., Gardin, S., Bartolini, A., Paris, G., Beaumont, V. \& GueX, J. 2010: Bentho-planktonic evidence from the Austrian Alps for a decline in sea-surface carbonate production at the end of the Triassic. — Swiss Journal of Geosciences 103/2, $293-315$. https://doi.org/10.1007/s00015-010-0019-z

Cobianchi, M. \& PicotTi, V. 2001: Sedimentary and biological response to sea-level and palaeoceanographic changes of a LowerMiddle Jurassic Tethyan platform margin (Southern Alps, Italy). — Palaeogeography, Palaeoclimatology, Palaeoecology 169/3, 219-244. https://doi.org/10.1016/S0031-0182(01)00217-6

Cohen, A. S. \& Coe, A. L. 2007: The impact of the Central Atlantic Magmatic Province on climate and on the Sr- and Os-isotope evolution of seawater. - Palaeogeography, Palaeoclimatology, Palaeoecology 244/1-4, 374-390. https://doi.org/10.1016/ j.palaeo.2006.06.036

Courtillot, V. \& RenNe, P. R. 2003: On the ages of flood basalt events. — Comptes Rendus Geoscience 335/1, 113-140. https://doi.org/ 10.1016/s1631-0713(03)00006-3

CsÁszÁr G. \& OrAveCzné SchefFer A. 1987: Bakony, Bakonybél, Kóris-hegy. - Magyarország geológiai alapszelvényei. Magyar Állami Földtani Intézet, Budapest, 6 p.

Davies, J. H. F. L., Marzoli, A., Bertrand, H., Youbi, N., Ernesto, M. \& SchaltegGer, U. 2017: End-Triassic mass extinction started by intrusive CAMP activity. — Nature Communications 8, 15596. https://doi.org/10.1038/ncomms15596

DETRE Cs. 1981: A Duna-balparti triász rögök rétegtani helyzete. — Magyar Állami Földtani Intézet Évi Jelentés 1979-ról, 81-86.

DulaI, A. 2002: A Dunántúli-középhegység hettangi és kora-szinemuri (kora-jura) brachiopoda faunája I. - A Bakony természettudományi kutatásának eredményei 26, Bakonyi Természettudományi Múzeum, Zirc, 112 p.

Fowell, S. J., Cornet, B. \& Olsen, P. E. 1994: Geologically rapid Late Triassic extinctions: Palynological evidence from the Newark Supergroup. - In: KLeIN, G. D (ed.): Pangea: Paleoclimate, tectonics, and sedimentation during accretion, zenith, and breakup of a supercontinent. Geological Society of America Special Paper 288, Geological Society of America, Boulder, Colorado, $197-206$. https://doi.org/10.1130/spe288-p197

FÜLÖP J. 1975: Tatai mezozóos alaphegység-rögök. — Geologica Hungarica, Series Geologica 16, 1-228.

GALÁCZ, A. 1988: Tectonically controlled sedimentation in the Jurassic of the Bakony Mountains (Transdanubian Central Range, Hungary). - Acta Geologica Hungarica 31/3-4, 313-328.

GALÁCZ, A., VöRÖs, A. 1972: A bakony-hegységi jura fejlődéstörténeti vázlata a főbb üledékföldtani jelenségek kiértékelése alapján. — Földtani Közlöny 102, 122-135.

Galli, M. T., Jadoul, F., Bernasconi, S. M., Cirilli, S. \& Weissert, H. 2007: Stratigraphy and palaeoenvironmental analysis of the Triassic-Jurassic transition in the western Southern Alps (Northern Italy). - Palaeogeography, Palaeoclimatology, Palaeoecology 244/1-4, 52-70. https://doi.org/10.1016/j.palaeo.2006.06.023

Gawlick, H.-J., Frisch, W., Vecsei, A., Steiger, T. \& BöHM, F. 1999: The change from rifting to thrusting in the Northern Calcareous Alps as recorded in Jurassic sediments. — Geologische Rundschau 87/4, 644-657. https://doi.org/10.1007/s005310050237

Gawlick, H.-J., Missoni, S., Schlagintweit, F., Suzuki, H., Frisch, W., Krystyn, L., Blau, J. \& Lein, R. 2009: Jurassic tectonostratigraphy of the Austroalpine domain. - Journal of Alpine Geology 50, 1-152.

GÉCZY, B. 1971: Ammonite faunae from the Lower Jurassic standard profile at Lókút, Bakony Mountains, Hungary. — Annales Universitatis Scientiarum Budapestinensis de Rolando Eötvös nominate, Sectio Geologica 15, 47-76.

Goldhammer, R. K., Lehmann, P. J. \& Dunn, P. A. 1993: The origin of high-frequency platform carbonate cycles and third-order sequences (Lower Ordovician El Paso Group, West Texas): Constraints from outcrop data and stratigraphic modeling. - Journal of Sedimentary Petrology 63, 318-359.

GötZ, A. E., RuCKWIED, K., PÁlfy, J. \& HAAS, J. 2009: Palynological evidence of synchronous changes within the terrestrial and marine realm at the Triassic/Jurassic boundary (Csővár section, Hungary). — Review of Palaeobotany and Palynology 156/3-4, 401-409. https://doi.org/10.1016/j.revpalbo.2009.04.002

Greene, S. E., Martindale, R. C., Ritterbush, K. A., Bottjer, D. J., Corsetti, F. A. \& Berelson, W. M. 2012: Recognising ocean acidification in deep time: An evaluation of the evidence for acidification across the Triassic-Jurassic boundary. — Earth-Science Reviews 113/1-2, 72-93. https://doi.org/10.1016/j.earscirev.2012.03.009 
Guex, J., Schoene, B., Bartolini, A., Spangenberg, J., Schaltegger, U., O’dogherty, L., Taylor, D., Bucher, H. \& Atudorei, V. 2012: Geochronological constraints on post-extinction recovery of the ammonoids and carbon cycle perturbations during the Early Jurassic. — Palaeogeography Palaeoclimatology Palaeoecology 346, 1-11. https://doi.org/10.1016/j.palaeo.2012.04.030

GYôRI O. 2014: Paleofluidum-áramlási események nyomozása dunántúli-középhegységi mezozoos karbonátokban. — PhD értekezés, ELTE, Budapest, 147+XXI pp.

HAAS J. 1995: Az Északi Gerecse felsőtriász karbonát platform képződményei. — Földtani Közlöny 125, $259-293$.

HAAS, J. \& TARDY-FILÁCZ, E. 2004: Facies changes in the Triassic-Jurassic boundary interval in an intraplatform basin succession at Csővár (Transdanubian Range, Hungary). — Sedimentary Geology 168/1-2, 19-48. https://doi.org/10.1016/j.sedgeo.2004.03.002

HaAs J., Jocháné Edelényi E., Gidai L., Kaiser M., Kretzoi M. \& Oravecz J. 1984: Sümeg és környékének földtani felépítése. — Geologica Hungarica, Series Geologica 20, 1-353.

HaAs, J., TARdi-Filácz, E., OraVecz-Scheffer, A., GóczÁn, F. \& Dosztály, L. 1997: Stratigraphy and sedimentology of an Upper Triassic toe-of-slope and basin succession at Csővár, Hungary. — Acta Geologica Hungarica 40/2, 111-177.

HAAs, J., GöTZ, A. E. \& PÁLFY, J. 2010: Late Triassic to Early Jurassic palaeogeography and eustatic history in the NW Tethyan realm: New insights from sedimentary and organic facies of the Csôvár Basin (Hungary). — Palaeogeography Palaeoclimatology Palaeoecology 291/3-4, 456-468. https://doi.org/10.1016/j.palaeo.2010.03.014

Hallam, A. \& Wignall, P. B. 1999: Mass extinctions and sea-level changes. — Earth-Science Reviews 48, 217-250. https://doi.org/ $10.1016 / \mathrm{s} 0012-8252(99) 00055-0$

Hallam, A. 1990: The end-Triassic mass extinction event. — In: Sharpton, V. L. \& WARD, P. D. (eds): Global catastrophes in Earth history; An interdisciplinary conference on impacts, volcanism, and mass mortality. Geological Society of America Special Paper 247, Geological Society of America, Boulder, Colorado, 577-583. https://doi.org/10.1130/spe247-p577

Hallam, A. 2002: How catastrophic was the end-Triassic mass extinction? — Lethaia 35, 147-157. https://doi.org/10.1111/j.15023931.2002.tb00075.x

Harris, T. M. 1937: The fossil flora of Scoresby Sound East Greenland. Part 5: Stratigraphic relations of the plant beds. — Meddelelser om Groenland 112/2, 1-112.

HaUtmann, M. 2004: Effect of end-Triassic $\mathrm{CO}_{2}$ maximum on carbonate sedimentation and marine mass extinction. - Facies 50, 257261. https://doi.org/10.1007/s10347-004-0020-y

Hesselbo, S. P., Robinson, S. A., Surlyk, F. \& Piasecki, S. 2002: Terrestrial and marine mass extinction at the Triassic-Jurassic boundary synchronized with major carbon-cycle perturbation: A link to initiation of massive volcanism? — Geology 30/3, 251-254. https://doi.org/10.1130/0091-7613(2002)030<0251:TAMEAT>2.0.CO;2

Hesselbo, S. P., Robinson, S. A. \& Surlyk, F. 2004: Sea-level change and facies development across potential Triassic-Jurassic boundary horizons, SW Britain. _ Journal of the Geological Society, London 161/3, 365-379. https://doi.org/10.1144/0016-764903033

Hesselbo, S. P., McRoberts, C. A. \& PÁlfy, J. 2007: Triassic-Jurassic boundary events: Problems, progress, possibilities. — Palaeogeography, Palaeoclimatology, Palaeoecology 244/1-4, 1-10. https://doi.org/10.1016/j.palaeo.2006.06.020

Hillebrandt, A. V., Krystyn, L., Kürschner, W. M., Bonis, N. R., Ruhl, M., Richoz, S., Schobben, M. A. N., Urlichs, M., Bown, P. R., Kment, K., McRoberts, C. A., Simms, M. \& Tomăsových, A. 2013: The Global Stratotype Sections and Point (GSSP) for the base of the Jurassic System at Kuhjoch (Karwendel Mountains, Northern Calcareous Alps, Tyrol, Austria). — Episodes 36/3, 162198.

Hodych, J. P. \& Dunning, G. R. 1992: Did the Manicouagan impact trigger end-of-Triassic mass extinction? - Geology 20, 51-54. https://doi.org/10.1130/0091-7613(1992)020<0051:DTMITE>2.3.CO;2

Holser, W. T., Magaritz, M. \& RipPerdan, R. L. 1996: Global isotopic events. — In: WALLISER, O. H. (ed.): Global events and event stratigraphy in the Phanerozoic. Springer, Berlin, 63-88. https://doi.org/10.1007/978-3-642-79634-0_6

Hori, R. S., FuJiki, T., InOue, E. \& KimurA, J.-I. 2007: Platinum group element anomalies and bioevents in the Triassic-Jurassic deepsea sediments of Panthalassa. — Palaeogeography, Palaeoclimatology, Pallaeoecology 244/1-4, 391-406. https://doi.org/10.1016/ j.palaeo. 2006.06 .038

HuYn, T. T. \& Poulsen, C. J. 2005: Rising atmospheric CO2 as a possible trigger for the end-Triassic mass extinction Palaeogeography, Palaeoclimatology, Palaeoecology 217/1-4, 223242. https://doi.org/10.1016/j.palaeo.2004.12.004

Kiessling, W. \& ABERHAN, M. 2007: Environmental determinants of marine benthic biodiversity dynamics through Triassic-Jurassic time. - Paleobiology 33/3, 414434. https://doi.org/10.1017/s0094837300026373

KIESSLING, W. \& SiMPSON, C. 2011: On the potential for ocean acidification to be a general cause of ancient reef crises. - Global Change Biology 17/1, 56-67. https://doi.org/10.1111/j.1365-2486.2010.02204.x

Kiessling, W., Aberhan, M., Brenneis, B. \& Wagner, P. J. 2007: Extinction trajectories of benthic organisms across the TriassicJurassic boundary. — Palaeogeography, Palaeoclimatology, Palaeoecology 224, 201-222. https://doi.org/10.1016/j.palaeo. 2006.06.029

Kocsis, Á. T., Kiessling, W. \& PÁLfy, J. 2014: Radiolarian biodiversity dynamics through the Triassic and Jurassic: implications for proximate causes of the end-Triassic mass extinction. — Paleobiology 40/4, 625-639. https://doi.org/10.1666/14007

Kocsis T. Á., SÁGHI K. \& PÁLfy J. 2015: A Paleobiology Database szerepe a modern őslénytani kutatásban. — Földtani Közlöny 145/1, 85-98.

KondA J. 1987: Magyarország geológiai alapszelvényei: Gerecse, Süttő, Vöröshídi-kőfejtő. — Magyar Állami Földtani Intézet, Budapest, $6 \mathrm{p}$.

KoRTE, C. 1999: ${ }^{87} \mathrm{Sr} /{ }^{86} \mathrm{Sr}-,{ }^{18} \mathrm{O}$ - und ${ }^{13} \mathrm{C}$-evolution des triassischen Meerwassers: geochemische und stratigraphische Untersuschungen an Conodonten und Brachiopoden. - Bochumer Geologische und Geotechnische Arbeiten 52, 1-171. 
Korte, C. \& KozUR, H. W. 2011: Bio- and chemostratigraphic assessment of carbon isotope records across the Triassic-Jurassic boundary at Csôvár quarry (Hungary) and Kendlbachgraben (Austria) and implications for global correlations. — Bulletin of the Geological Society of Denmark 59, 101-115.

Korte, C., Kozur, H. W., Bruckschen, P. \& Veizer, J. 2003: Strontium isotope evolution of Late Permian and Triassic seawater. Geochimica et Cosmochimica Acta 67/1, 47-62. https://doi.org/10.1016/s0016-7037(02)01035-9

Kovács Zs. 2016: A triász-jura határ a Dunántúli-középhegységben és korrelációs lehetốségei szénizotóp-sztratigráfia alapján. — MSc diplomamunka, Eötvös Loránd Tudományegyetem, Budapest, 93 p.

Kozur, H. 1993: First evidence of Liassic in the vicinity of Csővár (Hungary), and its paleogeographic and paleotectonic significance. — Jahrbuch der Geologischen Bundesanstalt 136/1, 89-98.

Kozur, H. \& Mock, R. 1991: New Middle Carnian and Rhaetian conodonts from Hungary and the Alps. Stratigraphic importance and tectonic implications for the Buda Mountains and adjacent areas. _ Jahrbuch der Geologischen Bundesanstalt 134/2, $271-297$.

LANTOS Z. 2004: Liász neptuni telérek és átülepített medenceüledékek nyomában: karbonátszedimentológiai esettanulmányok. — PhD értekezés, ELTE, Budapest, $141+$ XI p.

LATHUiličRe, B. \& MARCHAL, D. 2009: Extinction, survival and recovery of corals from the Triassic to Middle Jurassic time. — Terra Nova 21/1, 57-66. https://doi.org/10.1111/j.1365-3121.2008.00856.x

Lindström, S., van de Schootbrugge, B., Hansen, K. H., Pedersen, G. K., Alsen, P., Thibault, N., Dybkjćr, K., Bjerrum, C. J. \& NIELSEN, L. H. 2017: A new correlation of Triassic-Jurassic boundary successions in NW Europe, Nevada and Peru, and the Central Atlantic Magmatic Province: A time-line for the end-Triassic mass extinction. - Palaeogeography, Palaeoclimatology, Palaeoecology 478, 80-102. https://doi.org/10.1016/j.palaeo.2016.12.025

Marzoli, A., Renne, P. R., Piccirillo, E. M., Ernesto, M., Bellieni, G. \& De Min, A. 1999: Extensive 200-million-year-old continental flood basalts of the Central Atlantic Magmatic Province. - Science 284/5414, 616-618. https://doi.org/10.1126/science. 284.5414.616

McElwain, J. C., Beerling, D. J. \& Woodward, F. I. 1999: Fossil plants and global warming at the Triassic-Jurassic boundary. Science 285/5432, 1386-1390. https://doi.org/10.1126/science.285.5432.1386

McElwain, J. C., Popa, M. E., Hesselbo, S. P., Haworth, M. \& Surlyk, F. 2007: Macroecological responses of terrestrial vegetation to climatic and atmospheric change across the Triassic/Jurassic boundary in East Greenland. - Paleobiology 33/4, 547-573. https://doi.org/10.1666/06026.1

McElwain, J. C., WAGneR, P. J. \& Hesselbo, S. P. 2009: Fossil plant relative abundances indicate sudden loss of Late Triassic biodiversity in East Greenland. - Science 324/5934, 1554-1556. https://doi.org/10.1126/science.1171706

McRoberts, C. A., Krystyn, L. \& Hautmann, M. 2012: Macrofaunal response to the end-Triassic mass extinction in the west-Tethyan Kössen basin, Austria. — Palaios 27/9, 607-616. https://doi.org/10.2110/palo.2012.p12-043r

MindsZENTY A. 1992: Diagenezistörténeti vizsgálatok a tatai Kálvária-domb felsó-triász szelvényében. — Kutatási jelentés, Budapest. Magyar Állami Földtani, Geofizikai és Bányászati Adattár: VBK.1558, 20 pp.

Morrell, J. 2001: Genesis and geochronology: the case of John Phillips (1800-1874). — Geological Society, London, Special Publications 190/1, 85-90. https://doi.org/10.1144/gsl.sp.2001.190.01.07

Olsen, P. E., Shubin, N. H. \& ANDERs, M. H. 1987: New Early Jurassic tetrapod assemblages constrain Triassic-Jurassic tetrapod extinction event. - Science 237, 1025-1029. https://doi.org/10.1126/science.3616622

Olsen, P. E., Kent, D. V., Sues, H.-D., Koeberl, C., Huber, H., Montanari, A., Rainforth, E. C., Fowell, S. J., Szajna, M. J. \& HARTLINE, B. W. 2002: Ascent of dinosaurs linked to an iridium anomaly at the Triassic-Jurassic boundary. — Science 296/5571, 1305-1307. https://doi.org/10.1126/science.1065522

Olsen, P. E., Koeberl, C., Huber, H., Montanari, A., Fowell, S. J., Et-Touhami, M. \& Kent, D. V. 2002b: Continental TriassicJurassic boundary in central Pangea: Recent progress and discussion of an Ir anomaly. - In: KoEBERL, C. \& MACLEOD, K. G. (eds): Catastrophic Events and Mass Extinctions: Impacts and Beyond. Geological Society of America Special Paper 356, Geological Society of America, Boulder, 505-522. https://doi.org/10.1130/0-8137-2356-6.505

ORCHARD, M. J. 2010: Triassic conodonts and their role in stage boundary definition. — In: LuCAS, S. G. (ed.): The Triassic timescale. Geological Society, London, Special Publications 334, The Geological Society Publishing House, Bath, 139-161. https://doi.org/ $10.1144 / \mathrm{sp} 334.7$

PÁLFY, J. \& KoCSIS, T. Á. 2014: Volcanism of the Central Atlantic Magmatic Province as the trigger of environmental and biotic changes around the Triassic-Jurassic boundary. — In: KELLER, G. \& KERR, A. C. (eds): Volcanism, Impacts and Mass Extinctions: Causes and Effects. Geological Society of America Special Paper 505, Geological Society of America, Boulder, CO, 245-261. https://doi.org/ $10.1130 / 2014.2505(12)$

PÁLfy, J. \& ZAJZON, N. 2012: Environmental changes across the Triassic-Jurassic boundary and coeval volcanism inferred from elemental geochemistry and mineralogy in the Kendlbachgraben section (Northern Calcareous Alps, Austria). — Earth and Planetary Science Letters 335, 121-134. https://doi.org/10.1016/j.epsl.2012.01.039

PÁlfy, J., Mortensen, J. K., Carter, E. S., Smith, P. L., Friedman, R. M. \& TipPer, H. W. 2000: Timing the end-Triassic mass extinction: First on land, then in the sea? — Geology 28/1,39-42. https://doi.org/10.1130/0091-7613(2000)28\%3C39:ttemef\%3E2.0.co;2

PÁlfy, J., Demény, A., HaAs, J., Hetényi, M., Orchard, M. \& Vetó, I. 2001: Carbon isotope anomaly and other geochemical changes at the Triassic-Jurassic boundary from a marine section in Hungary. — Geology 29/11, 1047-1050. https://doi.org/10.1130/00917613(2001)029<1047:CIAAOG>2.0.CO;2

PÁlfy, J., Demény, A., HaAs, J., CArter, E. S., Görög, Á., Halász, D., OraVecz-Scheffer, A., Hetényi, M., Márton, E., Orchard, M. J., Ozsvírt, P., Vetô, I. \& ZAJZon, N. 2007a: Triassic-Jurassic boundary events inferred from integrated stratigraphy of the Csôvár section, Hungary. — Palaeogeography, Palaeoclimatology, Palaeoecology 244/1-4, 11-33. https://doi.org/10.1016/j.palaeo. 2006.06.021 
PÁlfy J., Dulai A. \& Szente I. 2007b: Kálvária-dombi kőfejtő nyugati udvara. — In: Pálfy J. \& PazonYI P. (szerk.): Ő́slénytani kirándulások Magyarországon és Erdélyben. Hantken Kiadó, Budapest, 41-44.

Palotai, M., PÁlfy, J. \& SASVÁRI, Á. 2017: Structural complexity at and around the Triassic-Jurassic GSSP at Kuhjoch, Northern Calcareous Alps, Austria. — International Journal of Earth Sciences 106/7, 2475-2487. https://doi.org/10.1007/s00531-017-1450-4

PicotTi, V. \& Cobianchi, M. 1996: Jurassic periplatform sequences of the Eastern Lombardian Basin (Southern Alps): The deep-sea record of the tectonic evolution, growth and demise history of a carbonate platform. - Memorie di Scienze Geologiche (Padova) 48 , 171-219.

Rampino, M. R., Haggerty, B. M. \& Pagano, T. C. 1997: A unified theory of impact crises and mass extinctions: Quantitative tests. Annals of the New York Academy of Sciences 822/1, 403-431. https://doi.org/10.1111/j.1749-6632.1997.tb48358.x

Raup, D. M. 1992: Large-body impact and extinction in the Phanerozoic. — Paleobiology 18/1, 80-88. https://doi.org/10.1017/ s0094837300012227

RAUP, D. M. \& SEPKOSKI, J. J., Jr. 1982: Mass extinctions in the marine fossil record. — Science 215, 1501-1503. https://doi.org/ 10.1126/science.215.4539.1501

Remane, J. 2003: Chronostratigraphic correlations: their importance for the definition of geochronologic units. — Palaeogeography, Palaeoclimatology, Palaeoecology 196/1-2, 7-18. https://doi.org/10.1016/s0031-0182(03)00310-9

RENNE, P. R. \& BASU, A. R. 1991: Rapid eruption of the Siberian Traps flood basalts at the Permo-Triassic boundary. - Science 253, 176179. https://doi.org/10.1126/science.253.5016.176

Richoz, S., van de Schootbrugge, B., Pross, J., Puttmann, W., Quan, T. M., Lindstrom, S., Heunisch, C., Fiebig, J., Maquil, R., Schouten, S., Hauzenberger, C. A. \& Wignall, P. B. 2012: Hydrogen sulphide poisoning of shallow seas following the end-Triassic extinction. - Nature Geoscience 5, 662-667. https://doi.org/10.1038/ngeo1539

Ruckwied, K., Götz, A. E., PÁLfy, J. \& TöRÖK, Á. 2008: Palynology of a terrestrial coal-bearing series across the Triassic/Jurassic boundary (Mecsek Mts., Hungary). — Central European Geology 51/1, 1-15. https://doi.org/10.1556/ceugeol.51.2008.1.1

RUHL, M. \& KÜRSCHNER, W. M. 2011: Multiple phases of carbon cycle disturbance from large igneous province formation at the TriassicJurassic transition. — Geology 39/5, 431-434. https://doi.org/10.1130/g31680.1

RuHL, M., KUERSCHNER, W. M. \& KRYSTYN, L. 2009: Triassic-Jurassic organic carbon isotope stratigraphy of key sections in the western Tethys realm (Austria). — Earth and Planetary Science Letters 281/3-4, 169-187. https://doi.org/10.1016/j.epsl.2009.02.020

Schaller, M. F., Wright, J. D. \& Kent, D. V. 2011: Atmospheric $p \mathrm{CO}_{2}$ perturbations associated with the Central Atlantic Magmatic Province. - Science 331/6023, 1404-1409. https://doi.org/10.1126/science.1199011

Schlager, W. \& Ginsburg, R. N. 1981: Bahama carbonate platforms — The deep and the past, Marine Geology 44/1-2, 1-24. https://doi.org/10.1016/0025-3227(81)90111-0.

Schoene, B., GueX, J., Bartolini, A., Schaltegger, U. \& Blackburn, T. J. 2010: Correlating the end-Triassic mass extinction and flood basalt volcanism at the $100 \mathrm{ka} \mathrm{level.} \mathrm{—} \mathrm{Geology} \mathrm{38/5,387-390.} \mathrm{https://doi.org/10.1130/G30683.1}$

Schulte, P., Alegret, L., Arenillas, I., Arz, J. A., Barton, P. J., Bown, P. R., Bralower, T. J., Christeson, G. L., Claeys, P., Cockell, C. S., Collins, G. S., Deutsch, A., Goldin, T. J., Goto, K., Grajales-Nishimura, J. M., Grieve, R. A. F., Gulick, S. P. S., Johnson, K. R., Kiessling, W., Koeberl, C., Kring, D. A., Macleod, K. G., Matsui, T., Melosh, J., Montanari, A., Morgan, J. V., Neal, C. R., Nichols, D. J., Norris, R. D., Pierazzo, E., Ravizza, G., Rebolledo-Vieyra, M., Reimold, W. U., Robin, E., Salge, T., SpeiJer, R. P., Sweet, A. R., Urrutia-Fucugauchi, J., Vajda, V., Whalen, M. T. \& Willumsen, P. S. 2010: The Chicxulub asteroid impact and mass extinction at the Cretaceous-Paleogene boundary. — Science 327/5970, 1214-1218. https://doi.org/10.1126/science.1177265

SIGNOR, P. W. \& LIPPS, J. H. 1982: Sampling bias, gradual extinction patterns and catastrophes in the fossil record. — In: SILVER, L. T. \& SchULTZ, P. H. (eds): Geological Implications of Impacts of Large Asteroids and Comets on the Earth. Geological Society of America Special Paper 190. Geological Society of America, Boulder, Colorado, 291-296. https://doi.org/10.1130/spe190-p291

Sobolev, S. V., Sobolev, A. V., Kuzmin, D. V., Krivolutskaya, N. A., Petrunin, A. G., Arndt, N. T., Radko, V. A. \& Vasiliev, Y. R. 2011: Linking mantle plumes, large igneous provinces and environmental catastrophes. - Nature 477/7364, 312-316. https://doi.org/10.1038/nature10385

Steinthorsdottir, M., Jeram, A. J. \& McElwain, J. C. 2011: Extremely elevated $\mathrm{CO}_{2}$ concentrations at the Triassic/Jurassic boundary. — Palaeogeography, Palaeoclimatology, Palaeoecology 308/3-4, 418-432. https://doi.org/10.1016/j.palaeo.2011.05.050

TAnner, L. H., LuCAS, S. G. \& Chapman, M. G. 2004: Assessing the record and causes of Late Triassic extinctions. - Earth-Science Reviews 65/1-2, 103-139. https://doi.org/10.1016/s0012-8252(03)00082-5

van de Schootbrugge, B., Tremolada, F., Rosenthal, Y., Bailey, T. R., Feist-Burkhardt, S., Brinkhuis, H., Pross, J., Kent, D. V. \& FAlKowsKi, P. G. 2007: End-Triassic calcification crisis and blooms of organic-walled 'disaster species'. - Palaeogeography, Palaeoclimatology, Palaeoecology 244/1-4, 126-141. https://doi.org/10.1016/j.palaeo.2006.06.026

van de Schootbrugge, B., Payne, J. L., Tomasovych, A., Pross, J., Fiebig, J., Benbrahim, M., Follmi, K. B. \& Quan, T. M. 2008: Carbon cycle perturbation and stabilization in the wake of the Triassic-Jurassic boundary mass-extinction event. — Geochemistry Geophysics Geosystems 9/4, 1-16. https://doi.org/10.1029/2007GC001914

van de Schootbrugge, B., Quan, T. M., Lindstrom, S., Puttmann, W., Heunisch, C., Pross, J., Fiebig, J., Petschick, R., Rohling, H. G., Richoz, S., Rosenthal, Y. \& FALKOwSKI, P. G. 2009: Floral changes across the Triassic/Jurassic boundary linked to flood basalt volcanism. — Nature Geoscience 2, 589-594. https://doi.org/10.1038/ngeo577

van de Schootbrugge, B., Bachan, A., Suan, G., Richoz, S. \& PAyne, J. L. 2013: Microbes, mud and methane: cause and consequence of recurrent Early Jurassic anoxia following the end Triassic mass extinction. — Palaeontology 56/4, 685-709. https://doi.org/ 10.1111/pala.12034

VADÁsz E. 1910: A Duna-balparti idősebb rögök őslénytani és földtani viszonyai._Magyar Királyi Földtani Intézet Évkönyve 18/2, 101171. 
VIGH G. 1935: Adatok a Gerecse-hegység nyugati részének földtani ismeretéhez. — Magyar Királyi Földtani Intézet Évi Jelentése 192528-ról, 87-100.

VÖRÖs, A. 1991: Hierlatzkalk - a peculiar Austro-Hungarian Jurassic facies. — In: LOBITZER H. \& CsÁsZÁr G. (eds): Jubiläumsschrift 20 Jahre Geologische Zusammenarbeit Österreich - Ungarn. Wien, I: 145-154.

VöRös, A., GALÁcZ A. 1998: Jurassic palaeogeography of the Transdanubian Central Range (Hungary). — Rivista Italiana di Paleontologia e Stratigraphia 104/1, 69-84.

Ward, P. D., Haggart, J. W., Carter, E. S., Wilbur, D., Tipper, H. W. \& Evans, T. 2001: Sudden productivity collapse associated with the Triassic-Jurassic boundary mass extinction. - Science 292/11, 1148-1151. https://doi.org/10.1126/science.1058574

Wignall, P. B. 2001: Large igneous provinces and mass extinctions. - Earth-Science Reviews 53/1-2, 1-33. https://doi.org/ 10.1016/s0012-8252(00)00037-4

Wignall, P. B. \& Bond, D. P. G. 2008: The end-Triassic and Early Jurassic mass extinction records in the British Isles. — Proceedings of the Geologists Association 119, 73-84. https://doi.org/10.1016/s0016-7878(08)80259-3

Williford, K. H., Ward, P. D., Garrison, G. H. \& Buick, R. 2007: An extended organic carbon-isotope record across the TriassicJurassic boundary in the Queen Charlotte Islands, British Columbia, Canada. - Palaeogeography, Palaeoclimatology, Palaeoecology 244/1-4, 290-296. https://doi.org/10.1016/j.palaeo.2006.06.032

ZEMPOLICH, W. G. 1993: The drowning succession in Jurassic carbonates of the Venetian Alps, Italy: A record of supercontinent breakup, gradual eustatic rise, and eutrophication of shallow-water environments. - In: LouCKs, R. G. \& SARG, J. F. (eds): Carbonate Sequence Stratigraphy: Recent Developments and Applications. American Association of Petroleum Geologists Memoir 57, 63-105.

Kézirat beérkezett: 2017. 10. 27. 